\title{
Pet fur or fake fur? A forensic approach
}

\author{
Elena Pilli ${ }^{1 *}$, Rosario Casamassima ${ }^{2}$, Stefania Vai ${ }^{1}$, Antonino Virgili ${ }^{3}$, Filippo Barni ${ }^{4}$, Giancarlo D'Errico ${ }^{4}$, Andrea Berti ${ }^{4}$, \\ Giampietro Lago 5 and David Caramelli ${ }^{1}$
}

\begin{abstract}
Background: In forensic science there are many types of crime that involve animals. Therefore, the identification of the species has become an essential investigative tool. The exhibits obtained from such offences are very often a challenge for forensic experts. Indeed, most biological materials are traces, hair or tanned fur. With hair samples, a common forensic approach should proceed from morphological and structural microscopic examination to DNA analysis. However, the microscopy of hair requires a lot of experience and a suitable comparative database to be able to recognize with a high degree of accuracy that a sample comes from a particular species and then to determine whether it is a protected one. DNA analysis offers the best opportunity to answer the question, 'What species is this?' In our work, we analyzed different samples of fur coming from China used to make hats and collars. Initially, the samples were examined under a microscope, then the mitochondrial DNA was tested for species identification. For this purpose, the genetic markers used were the 125 and 165 ribosomal RNA, while the hypervariable segment I of the control region was analyzed afterwards, to determine whether samples belonged to the same individual.

Results: Microscopic examination showed that the fibres were of animal origin, although it was difficult to determine with a high degree of confidence which species they belonged to and if they came from a protected species.

Therefore, DNA analysis was essential to try to clarify the species of these fur samples.

Conclusions: Macroscopic and microscopic analysis confirmed the hypothesis regarding the analyzed hair belonging to real animals, although it failed to prove with any kind of certainty which actual family it came from, therefore, the species remains unknown. Sequence data analysis and comparisons with the samples available in GenBank showed that the hair, in most cases, belonged to the Canidae family, and in one case only to Felidae.
\end{abstract}

Keywords: Fur samples, High degraded samples, Microscopic analysis, mtDNA, Species identification

\section{Background}

Forensic analysis tends to focus mainly on human DNA typing, but this is not the only source of DNA that can be found at a crime scene. Many types of crime involve nonhuman DNA samples, such as those of animals, plants, pollen, bacterial and viruses [1-4]. Despite being a relatively new subdiscipline of forensic science, the interest of the forensic community regarding nonhuman DNA samples is considerable, as evidenced by [5]. The identification of a species and the linking of a sample to a specific individual are becoming important tools in forensic investigation, owing to an increase in wildlife crime. One of the main reasons for the increase of

\footnotetext{
*Correspondence: elena.pilli@unifi.it

'Dipartimento di Biologia, Università di Firenze, via del Proconsolo 12, 50122 Florence, Italy

Full list of author information is available at the end of the article
}

wildlife crime probably comes from the fact that it is highly profitable and the penalties for guilty people are often light. Most of the time, the potential profit far outweighs the maximum penalty for the alleged crime [6]. Interpol estimates that illegal wildlife trade is the largest black market worldwide, second only to the traffic in drugs [7-9].

Many mammalian species, such as tigers, elephants, bears, rhinoceroses, and, mainly, reptiles and amphibians are trafficked every year around the world [10-19]. Crimes range from the abuse of illegal trade in protected species, or parts of them, such as horns, eggs [20] and tusks used to make ornaments or jewellery [21-26] or fur used to make gloves, hats and collars, to poaching and hunting out of season and many others. Italy was the first in Europe, and second in the world after the USA, to have imposed a ban on imports and the domestic 
trade of skins and furs from protected animals, firstly, through the ordinances of Dr Sirchia, the Minister of Health, issued in 2001 and renewed within two years, and then, in 2004, with the inclusion of the prohibition into the law against the mistreatment of animals [27]. The Italian law (article 2) prohibits the use of skins and furs for commercial purposes: 'Dogs (Canis familiaris) and cats (Felis catus) may not be used in the production or packaging of skins, furs, clothing and leather goods made or produced, in whole or in part, from the their skins or fur, as well as their skins or fur, cannot be marked or introduced into the national territory. Violation shall be punishable by imprisonment for periods of three months to one year or by a fine from 5,000 to 100,000 euros'. Therefore, the ability to identify a particular species and the capacity to determine whether the biological sample belongs to a specific individual of that species are an important tool in investigations.

Morphologic and structural microscopic analyses are the first approach in investigating the nature of the samples, excluding synthetic origins of the fibres, distinguishing between human and animal hair and trying to identify the species. These techniques are also important in comparing the features of the questioned hair with those collected from a known individual. In the case of animal hair, it is important to focus on shapes and sizes, colour banding, cuticular patterns, medulla organization, root structure and scales for its identification. A table presented in the Encyclopedia of Forensic Science [28] shows in detail all animal hair characteristics and traits that have to be considered during microscopic examination. Moreover, an adequate reference collection is essential for accurate identification of samples. Indeed, the wide variation in characteristics of hair taken from different body areas on the same animal and the large differences among animals that can occur within the same species do not allow the identification of the species of animal hair if a complete and accurate reference sample of hair is not available. Furthermore, much experience in microscopic hair analysis is required before one can confirm with a high degree of confidence whether or not a sample belongs to a protected species. However, even with experience, sometimes only the taxonomic rank of family may be identified.

When species identification using these methods is inconclusive, the only possible solution is to resort to more expensive DNA analysis. The application of DNAbased technologies to species identification has made the investigation of wildlife crimes possible. For several reasons, the DNA markers used in forensic species identification are located in the mitochondrial genome and derived from taxonomic and phylogenetic studies [29]. One of the main reasons for choosing mitochondrial DNA (mtDNA) as a forensic marker in identification studies is that there is no recombination. With the exception of mutations, all the mtDNA molecules of an individual are equal and inherited through the maternal line [30,31]. Moreover, the mtDNA molecules are present in multiple copies per cell [32] and the mitochondrion has a protein coat that helps to protect it from degradation: in highly degraded samples, such as bones, teeth and, obviously, the hair shaft [33-39], these characteristics make this approach more suitable than the nuclear DNA approach. Additionally, enzymes in the mitochondria are not able to read and correct DNA bases added incorrectly during replication [40], so that mutations can be accumulated in mtDNA up to five times more quickly than those accumulated during nuclear DNA replication.

There are many studies of species identification and many different markers can be utilized. The choice of marker for forensic species identification shows little intraspecific variability, that is, variability between members of the same species, but demonstrates sufficient interspecific variability, that is, between members of different species, to discriminate between individuals of different species. One of these loci is cytochrome $b$ [41-43]. Over the years, several forensic and taxonomic studies have utilized cytochrome $b$ as a marker for species identification [44-56]. However, more recently, there has been an increase in the use of another marker called cytochrome c oxidase I (COI). This is used in DNA barcoding; it has been adopted as a marker by the Barcode for Life Consortium [57-60]. Initially, it was used in the identification of invertebrate species [61-65]; for example, it has been exploited as a marker in forensic entomology to identify the beetle larvae on a corpse $[66,67]$. Since then, COI has been proposed for the identification of many organisms [68-82]. Other mitochondrial genes can be utilized as markers in forensic species identification: $12 S$ ribosomal RNA [83-85], $16 S$ ribosomal RNA [86-88] and the $N D H$ family [89,90]. While all these genes have been investigated for species identification, the D-loop analysis has mostly been exploited for intraspecies identification [91-96], though sometimes it can be applied to species identification [23,43,85,97-99]. Usually, the standard analysis of species identification requires amplification of part of these genes, followed by sequencing and comparison of the obtained sequence with reference sequences kept in a database, such as GenBank.

Here, we report a case of the alleged illegal trade of a protected species of fur. Our work consisted of ascertaining whether the furs had a synthetic origin or belonged to Canis lupus familiaris, Felis silvestris catus or other species. Furthermore, we had to assess whether the different furs belonged to the same individual. Initially, we focused on ruling out a synthetic origin for the fur and on trying to assess which species the hair 
belonged to by microscopic analysis. Finally, the species was identified by DNA analysis. The genetic markers used were $12 S$ and $16 S$ rRNA and the control region (hypervariable segment I, HVS-I) for individual identification. The advantages of this assay were: (1) the abundance of the mtDNA genome, (2) the broad reactivity of the primers that permitted the amplification of the DNA from unknown samples, (3) the small size of the amplicons, particularly the $12 S$ rRNA, which was $\approx 150$ base pairs (bp) and (4) the amplification of seven overlapping HVS-I fragments with sizes ranging from 130 to $250 \mathrm{bp}$.

\section{Methods}

\section{Samples}

Twelve fur samples (named A1, A2, A3, A4, A5, B1, B2, B3, B4, B5, B6 and B7) of alleged animal origin from protected species, in Italy, coming from China and used to make hats and collars, were seized just outside Genoa. In Italy, since the law 189/2004 has prohibited use of the skins and furs of domestic dogs (Canis lupus familiaris) and cats (Felis silvestris catus) for commercial purposes, microscopic and DNA evidence was necessary to ascertain the origin of these fibres and permit identification of the species. The seized fur was of different colours: black, brown, grey and red. Despite being subjected to thermal, chemical and mechanical stress during the processing cycle of tanning, the furs showed an apparently good state of preservation. However the amount of DNA in hair [100] is low compared with other tissues. Indeed, hair cells undergo dehydration and catabolic breakdown of nucleic acids and organelles during keratinization. Nevertheless, forensic scientists have successfully amplified DNA from modern human hair [101] and analyzed mtDNA from degraded and old hair samples [102-105].

\section{Microscopic analysis Stereomicroscopy}

First, the samples were carefully observed using a Leica $M$ 651 stereomicroscope (Leica Microsystems Srl, Milano, Italy). This allowed the observation of samples in three dimensions, thereby avoiding the flattening effect typical of other microscopes. At low magnifications of approximately $6.5 \times$ to $40 \times$, this analysis permitted the reproduction a three-dimensional image in direct vision and the examination of colour, texture, structure and treatment effects of samples.

\section{Light microscopy}

In forensic laboratories, the examination of the internal structures of this type of sample is typically carried out using a light microscope. Therefore, the hair samples were prepared for microscopic examination by placing them on glass slides with a colourless mounting medium in the refractive index range of 1.5 to 1.60 . The mounting medium utilized was Hi-MO (Bio Optica, Milano S.p.A., Italy) with a refractive index of 1.5 . To see a cuticular pattern more clearly, it was necessary to make a scale cast of the hair specimens. A thin coating of clear nail polish was set on a microscope slide. While still wet, each hair was positioned in the nail polish, ensuring that the entire length of the hair was included. Then, when the nail polish was completely dry, the hair was gently removed to obtain the scale cast [106]. To prevent contamination of each fur sample, the microscope slides were prepared under a hood. The light microscope utilized was a Leica DM LB2 (Leica Microsystems Srl, Milano, Italy).

\section{Genetic analysis \\ Highly degraded DNA analysis}

To obtain reliable results, owing to the stress caused by the tanning process and the characteristics of the hair, genetic analysis for these findings was conducted following the most stringent criteria proposed for ancient DNA studies [107-109]. Accepted authentication methods must be employed to assess the authenticity of the results. Different precautions were taken to avoid contamination of samples with extraneous DNA: (1) all DNA extraction and PCR involving the samples was carried out in a laboratory physically separated from the laboratory in which PCR cycling and post-PCR analyses were performed; (2) disposable masks, gloves and laboratory coats were worn throughout and were changed frequently; and (3) all DNA extractions and PCR reactions included negative controls. Repeated amplification from the same or different extracts from the same specimens are necessary: (1) to identify contamination of a particular extraction or amplification; (2) to allow DNA analysis when the extracts only sporadically contain DNA template molecules; and (3) to detect nucleotide misincorporations that produce consistent changes in the DNA molecule. In highly degraded samples, one of the most common modifications of (or damage caused to) the DNA molecule is the hydrolytic loss of amino groups from the nitrous bases [110]. The deamination products of cytosine (uracil), 5-methylcytosine (thymine) and adenine (hypoxanthine) have particular relevance to the amplification of ancient DNA, since they cause the incorrect bases (A instead of $G$ and $C$ instead of $\mathrm{T})$ to be inserted when new DNA strands are synthesized by a DNA polymerase [111,112]. In addition, jumping PCR', that is, the occurrence of template switching during PCR, may contribute to these substitutions. To distinguish between these two types of miscoding lesion, multiple amplifications of DNA extracts were performed and the PCR products were cloned. By comparing different clones from multiple amplifications, it will be possible to highlight the nucleotide differences that occur in all clones of one amplification from those that occur only sporadically [113]. A consensus sequence can be constructed from the selected 
clone sequences once data from possible jumping PCR events has been identified and removed. Bower et al. [114] demonstrated that 20 clones must be sampled from a single forensic or ancient DNA sample in order to determine a reliable consensus sequence.

DNA fragments derived from genomes of organelles, such as mitochondria [115], are often present in the nuclear genome [116] and, as reported by Jan den Tex et al. [117], they cause another problem for ancient DNA analysis. Since mitochondrial DNA is the molecule of interest in most ancient DNA projects, such nuclear integrations may occasionally be amplified by PCR and be mistaken for the organellar DNA sequences. This is particularly likely to happen if the primers used differ from the organellar DNA sequence in the individual specimen but not from the version of the same sequence that exists as a nuclear insertion. Erroneous conclusions regarding intraspecific variation [118], as well as species phylogenies [119], will then result. To prevent this problem, different primer sets can be used to amplify different overlapping fragments covering a target region, since it is very unlikely that two or more primer sets would preferentially amplify a particular nuclear insertion $[119,120]$. Furthermore, the use of multiple genes improves the chances of correctly identifying the species of the sample $[121,122]$.

\section{Sample preparation and DNA extraction}

Sample preparation, DNA extraction and PCR reaction setup were carried out in a laboratory dedicated to ancient DNA analysis. The pre-PCR area was physically separated from the area in which PCR cycling and postPCR analyses were conducted. The reagents, bench surface and nondisposable equipment were sterilized under ultraviolet light. Four or five hairs from each fur sample were decontaminated by soaking in a $5 \%$ bleach solution for $30 \mathrm{~s}$, followed by a rinse carried out initially in absolute ethanol and then in sterile distilled water. The samples were left to air-dry and then cut into small pieces, about 2 to $3 \mathrm{~mm}$, and collected in a sterile $1.5 \mathrm{ml}$ vial. The DNA extraction was performed according to the protocol of Gilbert et al. [105]. The fragmented samples were digested overnight at $55^{\circ} \mathrm{C}$ in a $0.5 \mathrm{ml}$ extraction buffer (modified, as to the protocol of Barnes et al. [123]) containing $0.01 \mathrm{M}$ Tris buffer, $0.01 \mathrm{M} \mathrm{NaCl}$ solution, $1 \%$ SDS, $0.5 \mathrm{mg} / \mathrm{ml}$ proteinase $\mathrm{K}, 10 \mathrm{mg} / \mathrm{ml}$ dithiothreitol and $0.001 \mathrm{M} \mathrm{N}$-phenacylthiazolium bromide. The DNA was extracted using a phenol-chloroform DNA extraction protocol, purified and concentrated by Amicon ultra $0.5 \mathrm{ml}$ centrifugal filters (Millipore), according to the user's manual, to yield a final volume of approximately $50 \mu \mathrm{l}$. At least two independent extracts were obtained from each fur sample. Negative controls were included in each extraction set.

\section{PCR amplification of $12 S$ and $16 \mathrm{~S}$}

Two microlitres of DNA from each extract were amplified as follows: $94^{\circ} \mathrm{C}$ for $10 \mathrm{~min}$ (Taq polymerase activation), followed by 40 cycles of PCR (denaturation, $94^{\circ} \mathrm{C}$ for $45 \mathrm{~s}$, annealing, $53^{\circ} \mathrm{C}$ for $1 \mathrm{~min}$ and extension, $72^{\circ} \mathrm{C}$ for $1 \mathrm{~min}$ ) and then a final step at $72^{\circ} \mathrm{C}$ for $10 \mathrm{~min}$. The $50 \mu$ reaction mix contained $2 \mathrm{U}$ of AmpliTaq Gold (Applied Biosystems), $200 \mu \mathrm{M}$ of each deoxyribonucleotide triphosphate (dNTP), $1.5 \mathrm{mM} \mathrm{MgCl}_{2}, 1 \times$ PCR buffer and $1 \mu \mathrm{M}$ of each primer. According to Melton et al. [84], the $12 S$ primer sequences amplified a $150 \mathrm{bp}$ fragment. According to Kitano et al. [85], the 165 primer sequences amplified a 244 bp fragment. Each extract was amplified in duplicate. The extraction reagent control, a known positive control (human DNA) and a negative PCR control were amplified in parallel. Thirty-five microlitres of each PCR product were analyzed by electrophoresis, on a $1.5 \%$ agarose gel for $45 \mathrm{~min}$ at $80 \mathrm{~V}$ and visualized with ethidium bromide. To identify the molecular-weight size of PCR products we used a $50 \mathrm{bp}$ ladder (New England BioLab Inc.). The PCR products were purified using a Montage ${ }^{\mathrm{ma}}$ DNA gel extraction kit (Millipore), according to the user's manual.

\section{PCR amplification of dog HVS-I}

The control region of dog mtDNA is $1270 \mathrm{bp}$ long and contains two hypervariable segments (HVS-I and HVSII) and a 10 nt variable number tandem repeat (VNTR) between HVS-I and HVS-II [95]. We analyzed the HVS-I region and, as recommended for analysis of ancient DNA samples, the hypervariable region was divided into overlapping fragments, to prevent the amplification of nuclear insertion and increase the probability of amplification success if the DNA is degraded and fragmented $[119,120]$. The 672-bp-long HVS-I was subdivided into seven overlapping fragments, using the primer pairs reported in Table 1. Some primer sequences, such as L15422/H15555 and L15511/H15692, utilized for analysis, were obtained from Verginelli et al. $[124,125]$. The other primers were designed using the Primer3 program [126]. The nomenclature of the primers corresponds with the $5^{\prime}$-end of the reference sequence, according to [127]. The size of PCR products ranged from 130 to $250 \mathrm{bp}$. The HVS-I was amplified in a final volume of $50 \mu \mathrm{l}$ in seven different assays including 2 $\mathrm{U}$ of AmpliTaq Gold (Applied Biosystems), $200 \mu \mathrm{M}$ of each dNTP, $1.5 \mathrm{mM} \mathrm{MgCl}, 1 \times$ PCR buffer and $1 \mu \mathrm{M}$ of each primer. Each fragment was amplified in duplicate. The extraction reagent control, a known positive control (dog DNA) and a negative PCR control were amplified in parallel. The PCR products were analyzed by electrophoresis on a $1.5 \%$ agarose gel, as described in the previous paragraph. 
Table 1 Primer pairs used to amplify the seven overlapping fragments of HVS-I with molecular details

\begin{tabular}{|c|c|c|c|c|c|}
\hline $\begin{array}{l}\text { Amplicon } \\
\text { size (bp) }\end{array}$ & $\begin{array}{l}\text { Primer } \\
\text { name }\end{array}$ & Primer range & Primer sequence $5^{\prime}-3^{\prime}$ & $\begin{array}{l}\text { Sequence } \\
\text { information } \\
\text { range (bp) }\end{array}$ & Reference \\
\hline 170 & $\begin{array}{l}\text { L15422 } \\
\text { H15555 }\end{array}$ & $\begin{array}{l}15404-15422 \\
15555-15574\end{array}$ & $\begin{array}{l}\text { CTCTTGCTCCACCATCAGC } \\
\text { TTATATGCATGGGGCAAACC }\end{array}$ & 133 & [124] \\
\hline 219 & $\begin{array}{l}\text { L15511 } \\
\text { H15692 }\end{array}$ & $\begin{array}{l}15490-15511 \\
15692-15709\end{array}$ & $\begin{array}{l}\text { ACTGTGCTATGTCAGTATCTCC } \\
\text { TTGATGGTITCTCGAGGC }\end{array}$ & 181 & [124] \\
\hline 246 & $\begin{array}{l}\text { L15574 } \\
\text { H15780 }\end{array}$ & $\begin{array}{l}15555-15574 \\
15780-15801\end{array}$ & $\begin{array}{l}\text { GGTTTGCCCCATGCATATAA } \\
\text { AAGTAAGAACCAGATGCCAGGT }\end{array}$ & 206 & {$[126]$} \\
\hline 148 & $\begin{array}{l}\text { L15764 } \\
\text { H15873 }\end{array}$ & $\begin{array}{l}15744-15764 \\
15873-15892\end{array}$ & $\begin{array}{l}\text { CCCATACTAACGTGGGGGTTA } \\
\text { TGTGTGATCATGGGCTGATT }\end{array}$ & 109 & {$[126]$} \\
\hline 129 & $\begin{array}{l}\text { L15857 } \\
\text { H15945 }\end{array}$ & $\begin{array}{l}15836-15857 \\
15945-15965\end{array}$ & $\begin{array}{l}\text { ATTCTCGCAAATGGGACATC } \\
\text { GCGGTCGTAGGTGAGTGATAG }\end{array}$ & 88 & [126] \\
\hline 137 & $\begin{array}{l}\text { L15892 } \\
\text { H15991 }\end{array}$ & $\begin{array}{l}15873-15892 \\
15991-16010\end{array}$ & $\begin{array}{l}\text { AATCAGCCCATGATCACACA } \\
\text { GGCATATTCCCTGAGAGCAG }\end{array}$ & 99 & {$[126]$} \\
\hline 154 & $\begin{array}{l}\text { L15982 } \\
\text { H16097 }\end{array}$ & $\begin{array}{l}15963-15982 \\
16097-16117\end{array}$ & $\begin{array}{l}\text { CGCAACGGCACTAACTCTAA } \\
\text { TGTCCTGAAACCATTGACTGA }\end{array}$ & 115 & {$[126]$} \\
\hline
\end{tabular}

\section{Cloning and sequencing}

The PCR products were cloned using a TOPO TA Cloning Kit (Invitrogen), according to the manufacturer's instructions. Screening of 20 white recombinant colonies was accomplished by PCR, and the colonies were transferred into a $30 \mathrm{ml}$ reaction mix $(67 \mathrm{mM}$ Tris $\mathrm{HCl}(\mathrm{pH}$ 8.8), $2 \mathrm{mM} \mathrm{MgCl}_{2}, 1 \mathrm{mM}$ of each primer, $0.125 \mathrm{mM}$ of each dNTP, 0.75 units of Taq polymerase) containing M13 forward and reverse universal primers. After $5 \mathrm{~min}$ at $92^{\circ} \mathrm{C}, 30$ cycles of PCR $\left(30 \mathrm{~s}\right.$ at $90^{\circ} \mathrm{C}, 1 \mathrm{~min}$ at $50^{\circ} \mathrm{C}, 1$ $\min$ at $72^{\circ} \mathrm{C}$ ) were carried out and clones with samples of the expected size were identified by agarose gel electrophoresis. After the purification of all PCR products, using a PureLink ${ }^{\mathrm{Tm}}$ PCR Purification kit $\left(\right.$ Invitrogen $^{\mathrm{Tm}}$ ), a volume of $1 \mu \mathrm{l}$ was cycle-sequenced using a BigDye Terminator v3.1 cycle sequencing kit ${ }^{\text {тм }}$ (Applied Biosystems), following the supplier's instructions. Sequencing involves initial denaturation at $96^{\circ} \mathrm{C}$ for $1 \mathrm{~min}$ followed by 25 cycles at $96^{\circ} \mathrm{C}$ for $10 \mathrm{~s}, 50^{\circ} \mathrm{C}$ for $5 \mathrm{~s}$ and $60^{\circ} \mathrm{C}$ for 4 min. Sequencing reaction products were purified from residual dye terminators using Agencourt $^{\oplus}$ CleanSEQ $^{\circ}$ (Beckman Coulter), according to the manufacturer's manual. Sequencing was carried out on Applied BioSystems $3130 \times 1$ Genetic Analyzer (Applied Biosystems) using POP7, $36 \mathrm{~cm}$ capillary arrays and the default instrument settings, as recommended by the manufacturer. The data were analyzed using SeqScape ${ }^{\circledast}$ Software Version 2.5 (Applied Biosystems) and default software settings, as recommended by the manufacturer. Twenty clones for each sample were sequenced, and the sequences obtained were aligned using the Clustal X program [128] and compared across clones. Then, for each sample, the consensus sequence of $12 S, 16 S$ and HVS-I was copied and pasted into the nucleotide-nucleotide BLAST function at the National Centre for Biotechnology Information (NCBI) website [129]. The BLAST portal generated a report showing the degree of sequence similarity with organisms in the NCBI database. If no NCBI reference presented a similarity of $100 \%$ with all the query sequences, further phylogenetic analyses were performed. Species identifications were made based on the percentage similarity of the query sequence to the reference sequence $(>98 \%)$ as described in previous papers $[20,130]$.

\section{Phylogenetic analysis}

A comparison dataset of sequences of the mitochondrial HVS-I was compiled, in order to represent the known intra- and interspecific variation between the species and subspecies for which almost $98 \%$ of similarity was detected by the nucleotide-nucleotide BLAST search with the results obtained from the fur samples. All the sequences (from the dataset and the fur samples) were analyzed using MEGA version 6 [131]; they were aligned using the MUSCLE algorithm [132], and the best substitution model was assessed and used to develop a neighbour-joining tree [133], including a bootstrap analysis with 1,000 replications, to determine which species or subspecies the fur samples clustered with.

\section{Results and discussion}

\section{Macroscopic and microscopic analysis}

The analysis of hair samples began with a macroscopic approach and then moved to a microscopic one. The visible characteristics of the samples were initially observed with the naked eye and described, and then studied using a stereomicroscope (macroscopic analysis) to determine colour, texture, structure and treatment effects of the samples. The seized samples consisted of fur of different colours (Table 2).

Some of the fur samples, such as A1, A2, A3, A4, A5, B5 and B6, were a natural colour, with the colour 
Table 2 Different colours of the seized furs

\begin{tabular}{ll}
\hline Samples & Colour of fur \\
\hline A1 & Banding: yellowish and black \\
A3 & Banding: yellowish and black \\
A4 & Banding: white and dark brown \\
A5 & Banding: white and dark brown \\
B1 & Banding: yellowish and black \\
B2 & Red with dark shades \\
B3 & Dark brown \\
B4 & Brown \\
B5 & Dark brown \\
B6 & Banding: white and dark brown \\
B7 & Banding: white and dark brown \\
\hline
\end{tabular}

changing over short distances (banding) (Figure 1). Others, such as B1, B2, B3, B4 and B7 were of artificial colours, roughly homogeneous (Figure 2).

The natural colour banding, only present in some samples, is a typical characteristic of several animal species, such as the mink, muskrat, raccoon, otter and many others, but is generally not typical of the cat or the dog. The homogeneous colour of the other samples was unnatural and led us to believe that the furs were dyed. Careful examination also revealed the presence of both longer, thicker hair and shorter, thinner hair. The observed differences in length and texture were compatible with animal furs: in mammalian species, with the exclusion of human beings and cetaceans, the longest and thickest hairs are known as guard hairs, while the shortest and thinnest are known as wool hairs. The guard hair protects the animal from rain and snow, and determines the colour of the coat, while the wool hair represents the bottom layer of the coat and its main

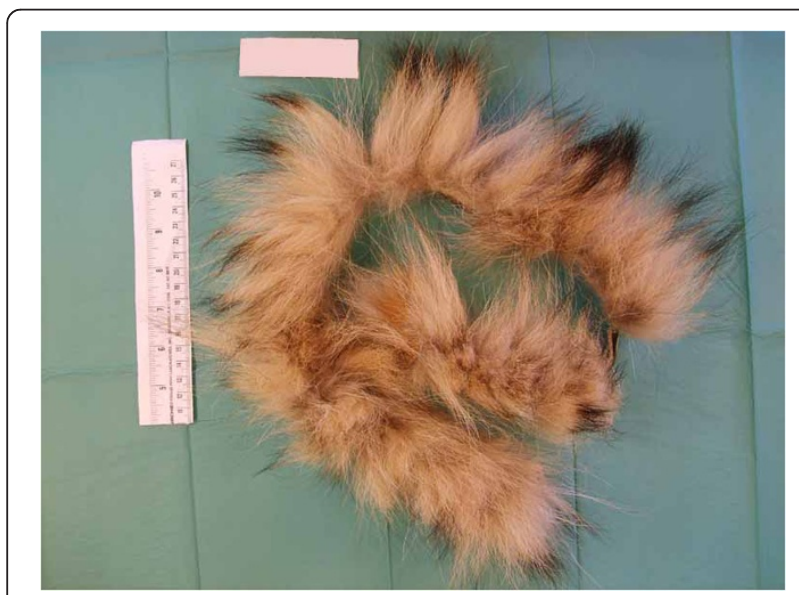

Figure 1 Sample A2. Example of colour changing over relatively short sections of the shaft of the sample. function is to keep the body temperature stable. Both guard and wool hair appeared heterogeneous in length, thickness and consistency. Moreover, a thorough inspection revealed that some of the hair seemed to originate from a single structure: this was probably due to complex hair follicles. The complex hair follicle, a typical structure of, for example, dog and cat hair, is an epidermal invagination in the dermis, whereby different hairs can grow from the same follicle. The internal structure of the hair was then investigated using a light microscope. Microscopic analysis showed the morphostructural characteristics of the hair. In particular, it confirmed the presence of three distinct layers from the outside inwards: the cuticle, the cortex and the medulla. The morphostructural characteristics observed for each hair are shown in Table 3.

The cuticle is a translucent layer of the hair shaft, consisting of scales covering the shaft. The observed cuticle scales ran from the root to the tip of the hair. In most samples, the structure of the scales was generally not prominent and showed an imbricate scale patterns (the double chevron of Table 3, shown in Figure 3); in others (B2, B4 -Figure 4- and B7) the scales were prominent and exhibited a spinous scale pattern (regular petal) that stuck out of the hair shaft and covered its entire length.

The nonprominent scale pattern is typical of dog hair, while the prominent scale pattern is typical of several animals, such as the sable, lynx, seal and cat. The cortex is the main body of the hair and is highly structured and organized. It is composed of elongated and fusiform cells with a pyknotic nucleus and fibrils that are the primary source of mechanical strength and water uptake. The cortical cells constitute the bulk of hair and the cortex provides the hair fibre with its eventual shape, resilience, elasticity and curl. In every sample, the cortex appeared uniform. However, in the cortex of some hair samples (A1, A3, A4, A5, B5 and B6, Table 3), an inhomogeneous

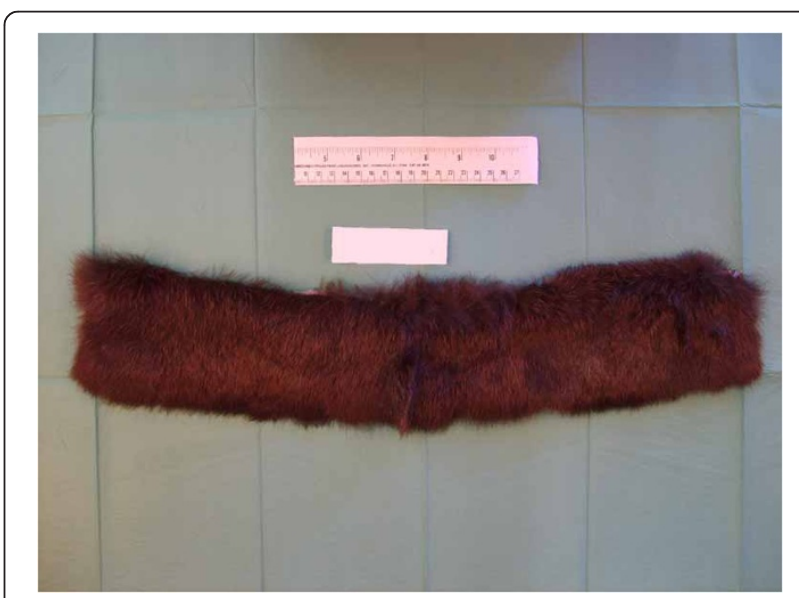

Figure 2 Sample B7. Example of the artificial, roughly homogeneous colour of the sample. 
Table 3 Morphostructural characteristics of the seized furs [134]

\begin{tabular}{|c|c|c|c|c|}
\hline Samples & Cuticle pattern & Cortex & Medulla pattern & Individual characteristics \\
\hline A1 & Double chevron & Uniform & Opaque unbroken cellular & Cortex: more dense towards medulla \\
\hline A2 & Double chevron & Uniform & Opaque unbroken cellular & Root shape: spade-like \\
\hline A3 & Double chevron & Uniform & Opaque unbroken cellular & Cortex: more dense towards medulla \\
\hline A4 & Double chevron & Uniform & Opaque unbroken & Cortex: more dense towards medulla \\
\hline A5 & Double chevron & Uniform & Vacuolated & Cortex: more dense towards medulla \\
\hline B1 & Double chevron & Uniform & Vacuolated & \\
\hline B2 & Regular petal & Uniform & Opaque unbroken & Medulla pattern: wide \\
\hline B3 & Double chevron & Uniform & Vacuolated & \\
\hline B4 & Regular petal & Uniform & Opaque unbroken or uniserial ladder & Medulla pattern not recognizable from cortex \\
\hline B5 & Double chevron & Uniform & Vacuolated & Cortex: more dense towards medulla \\
\hline \multirow[t]{2}{*}{ B6 } & Double chevron & Uniform & Vacuolated & Root shape: spade-like \\
\hline & & & & Cortex: more dense towards medulla \\
\hline B7 & Regular petal & Uniform & Vacuolated or uniserial ladder & Medulla pattern: wide \\
\hline
\end{tabular}

pigmentation was noted along the length of the hair, mainly spread over the centre of the medullary region (Figure 5). The medulla is the innermost region of the hair, and is not always present. As with the other morphological characteristics, even the medulla can be a useful parameter to identify the species. Indeed both the diameter of the medulla and its structure are typical features of particular species. The medulla appeared continuous along the structure of the hair in every sample examined. In most samples, the medulla was cellular (Figure 6) or vacuolated (Figure 7) (the typical structure of a dog's medulla) but in samples B2, B4 and B7 its structure was opaque unbroken and a uniserial ladder (Figure 8) (the representative configuration of a cat's medulla).

In these samples, the medulla appeared wide. Generally, in animal hair, the medulla occupies an area greater than one-third of the overall diameter of the hair shaft and its value can change slightly among different species.

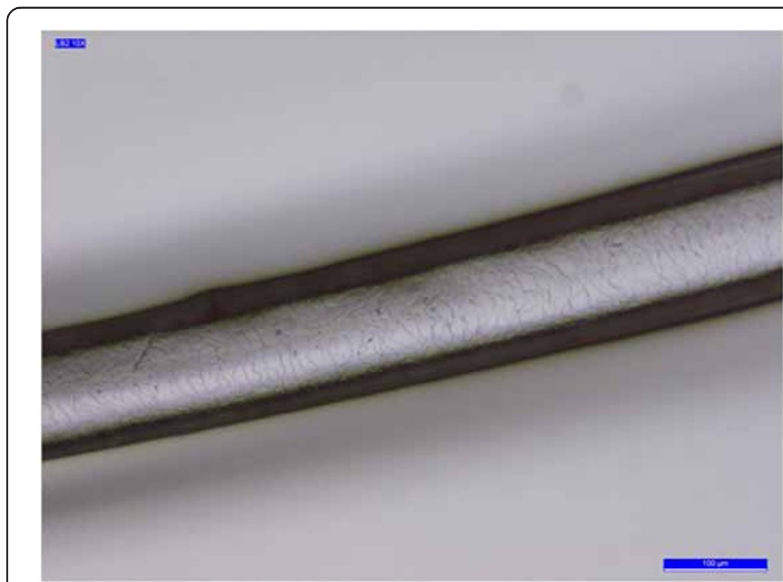

Figure 3 Sample A3. Example of the double-chevron scale pattern.
Table 4 shows the medullary index of each sample (guard hair).

As can be deduced by the values reported in Table 4, the hair samples presented a fairly uniform distribution of the medullary index value of about 0.6 to 0.7 ; however, the index was never higher than 0.8 for any sample.

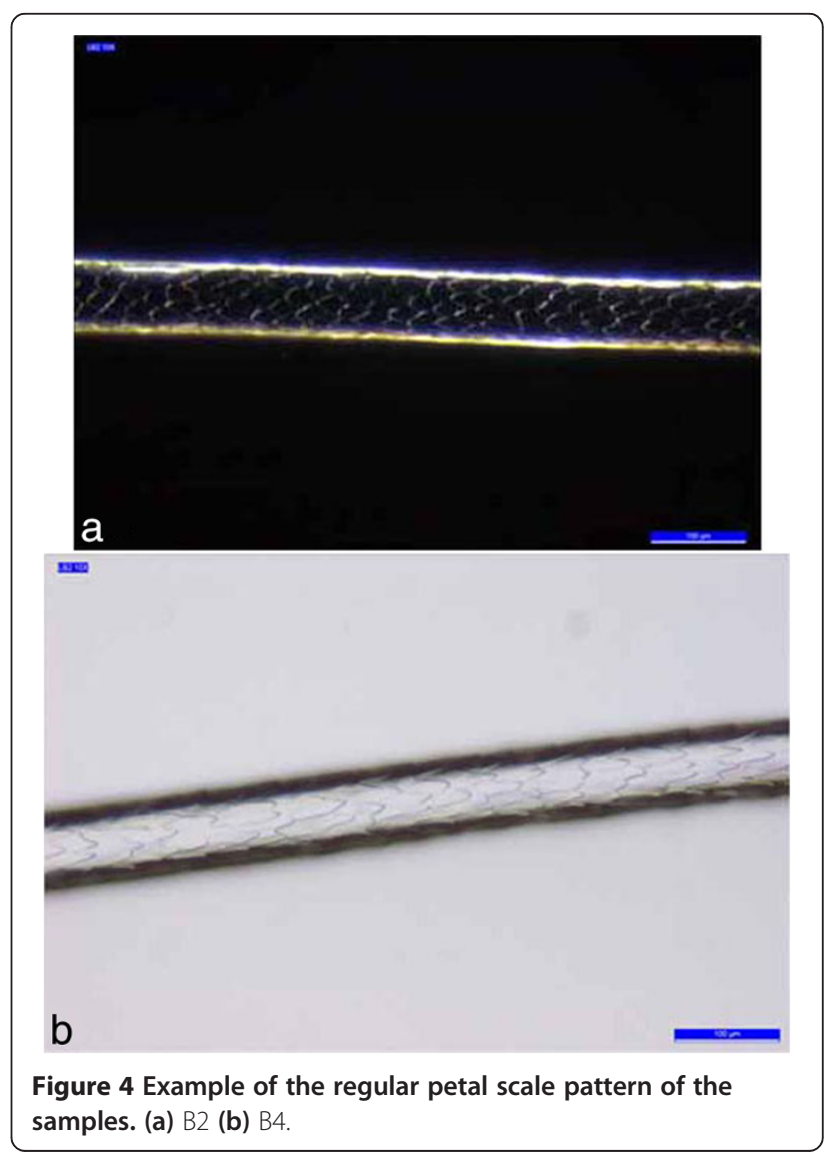




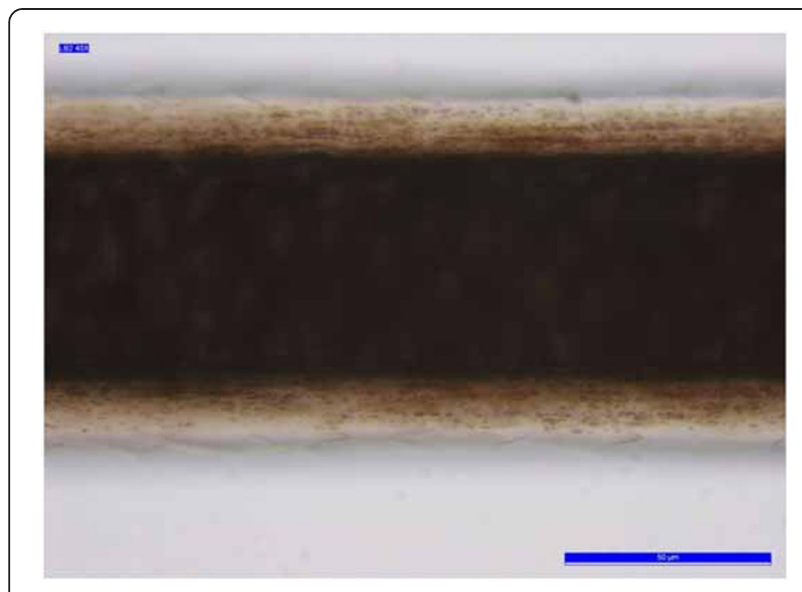

Figure $\mathbf{5}$ Sample A3. The cortex is more dense towards the medulla.

These values were compatible with those of animal hair; indeed animals have a medullary index ranging from 0.5 to 0.9 . However, despite the medullary index values being compatible with the Canidae and Felidae families, they were not indicative of any species in particular, since they ranged from half to three-quarters of the width, as is the case with the majority of species. In samples A2 and B6, microscopic analysis also showed the presence of spade-shaped roots. This is a typical characteristic of dog hair roots (Figure 9).

In summary, the furs appeared to be in good condition despite signs of physical and chemical stress due to tanning. These signs were particularly clear in the state of conservation of the underlying substrate and in the strong artificial dyeing of some hair. Microscopic inspection and evaluation of the medullary index [135] allowed us to establish the animal nature of the samples examined. The morphostructural data also provided an indication of the species to which the hair belonged, although they did not provide any kind of certainty

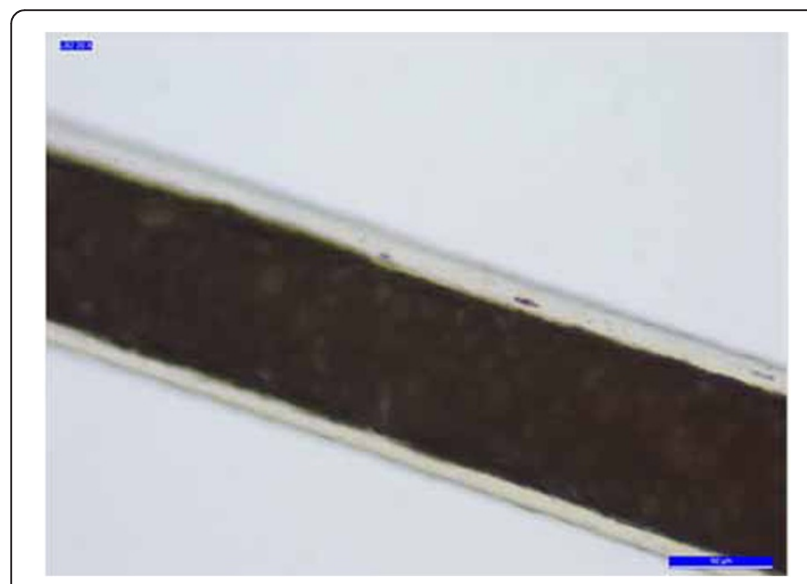

Figure 6 Sample A2. Example of cellular medulla pattern.

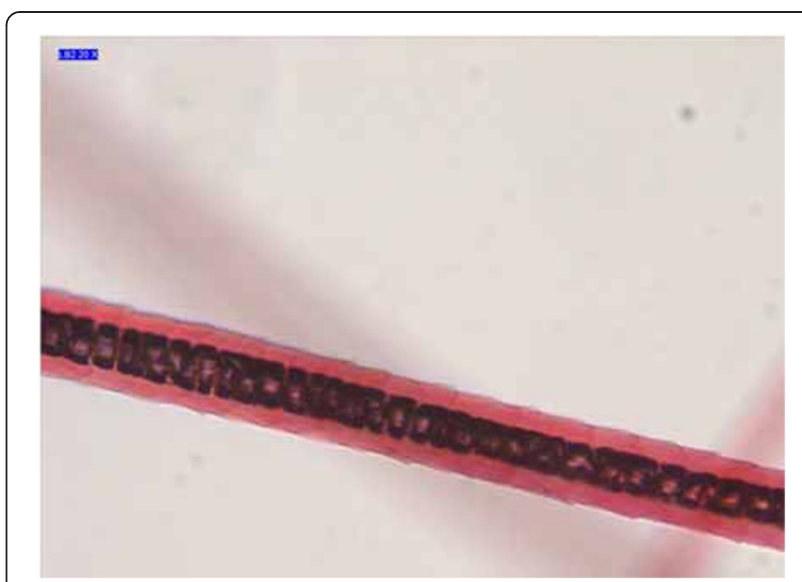

Figure 7 Sample B1. Example of vacuolated medulla pattern.

about the specific species. Samples A1, A2, A3, A4, A5, B1, B3, B5 and B6 appeared as a homogeneous group with similar features, both macroscopic and microscopic, although macroscopically B1 and B3 showed intense artificial colouring different from the other fur samples. Therefore, on the basis of macro- and microscopic analysis, it was plausible to hypothesize that they shared a common origin, which could be ascribed to both the Canidae and the Procyonidae family. Yet, while the cuticle patterns (double chevron) and medulla patterns (vacuolated) are features of the Canidae family and the spade-like root shape of samples A2 and B6 is a typical structure in the hair roots of dogs, the medulla patterns (cellular), medullary indices and colour banding of the fur were more similar to a laboratory comparison sample from a raccoon [136]. Moreover, samples B2, B4 and B7 could be considered a separate group, with the same artificial colour of fur and comparable morphostructural characteristics consistent with a feline origin.

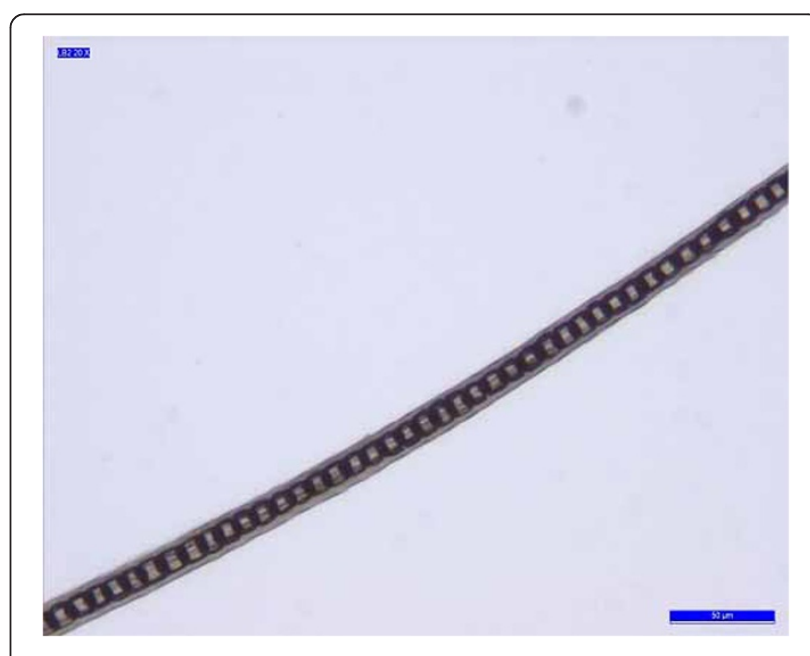

Figure 8 Sample B7. Example of uniserial ladder medulla pattern. 
Table 4 Medullary diameter, overall diameter of hair shaft and medullary index of hair samples

\begin{tabular}{llll}
\hline Samples & $\begin{array}{l}\text { Medullary } \\
\text { diameter }(\boldsymbol{\mu m})\end{array}$ & $\begin{array}{l}\text { Overall diameter } \\
\text { of hair shaft }(\boldsymbol{\mu m})\end{array}$ & $\begin{array}{l}\text { Medullary } \\
\text { index }\end{array}$ \\
\hline A1 & 94 & 122 & 0.77 \\
A2 & 81 & 103 & 0.78 \\
A3 & 56 & 85 & 0.66 \\
A4 & 73 & 113 & 0.65 \\
A5 & 38 & 54 & 0.70 \\
B1 & 45 & 66 & 0.68 \\
B2 & 42 & 64 & 0.68 \\
B3 & 43 & 70 & 0.61 \\
B4 & Not detected & 95 & Not detected \\
B5 & 91 & 147 & 0.61 \\
B6 & 51 & 85 & 0.60 \\
B7 & 30 & 40 & 0.75 \\
\hline
\end{tabular}

On the basis of the macroscopic and microscopic characteristics, it could be assumed that we were in the presence of hair belonging to the Canidae, Procyonidae or Felidae families. However, the identification of the family (Canidae or Procyonidae) and the species of these samples could not be confirmed by microscopic analysis, owing to the great variability of hair, the small amount of hair analyzed and the lack of a suitable comparative database or reference sample to compare the assay samples.

\section{Genetic and phylogenetic analysis}

Owing to the chemical and physical damage [109, 137-140] of the samples' DNA during the processing cycle of tanning, PCR amplification of the $12 S$ and 165 markers did not produce results in every sample analyzed. With regard to the $12 \mathrm{~S}$ marker, 10 samples out of 12 were successfully amplified, as shown in Table 5 . For

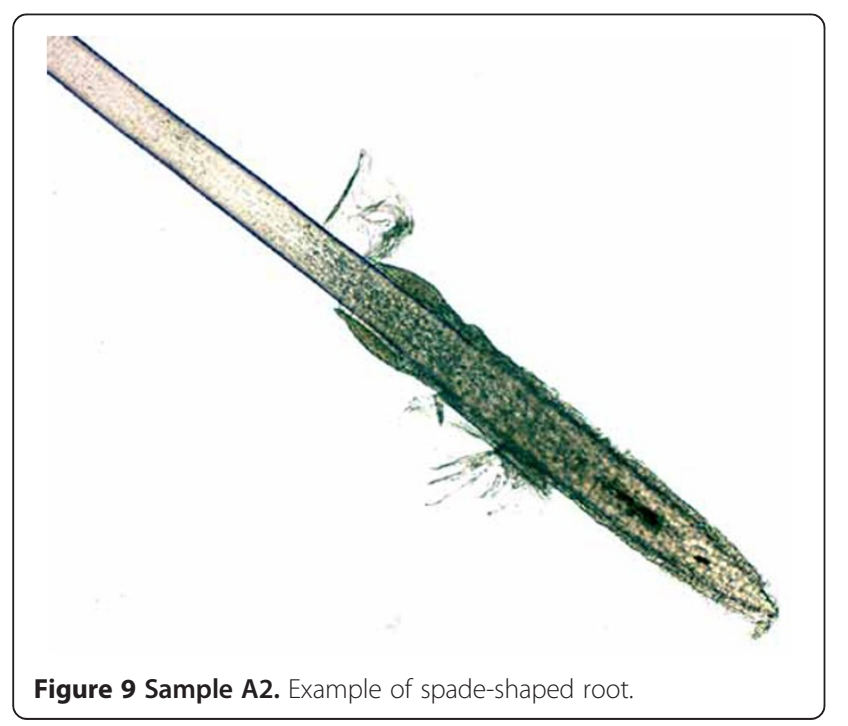

Table 5 Results of $12 S$ marker analysis

\begin{tabular}{|c|c|c|c|}
\hline $\begin{array}{l}\text { Sample } \\
\text { name }\end{array}$ & $\begin{array}{l}12 S \text { consensus } \\
\text { sequence }\end{array}$ & Identified species & $\begin{array}{l}\text { Percentage } \\
\text { similarity }\end{array}$ \\
\hline A1 & $\checkmark$ & $\begin{array}{l}\text { Canis lupus laniger, } \\
\text { Canis lupus chanco and } \\
\text { Canis lupus familiaris }\end{array}$ & $98 \%$ match \\
\hline $\mathrm{A} 2$ & $\checkmark$ & $\begin{array}{l}\text { Canis lupus laniger, } \\
\text { Canis lupus chanco and } \\
\text { Canis lupus familiaris }\end{array}$ & $98 \%$ match \\
\hline A3 & $\checkmark$ & $\begin{array}{l}\text { Canis lupus laniger, } \\
\text { Canis lupus chanco and } \\
\text { Canis lupus familiaris }\end{array}$ & $98 \%$ match \\
\hline A4 & $\checkmark$ & $\begin{array}{l}\text { Canis lupus laniger, } \\
\text { Canis lupus chanco and } \\
\text { Canis lupus familiaris }\end{array}$ & $98 \%$ match \\
\hline A5 & $\checkmark$ & Homo sapiens & $93 \%$ match \\
\hline B1 & $\checkmark$ & Homo sapiens & $93 \%$ match \\
\hline B2 & $\checkmark$ & Homo sapiens & $93 \%$ match \\
\hline B3 & $\checkmark$ & Homo sapiens & $93 \%$ match \\
\hline B4 & $=$ & Not available & \\
\hline B5 & $=$ & Not available & \\
\hline B6 & $\checkmark$ & $\begin{array}{l}\text { Canis lupus laniger, } \\
\text { Canis lupus chanco and } \\
\text { Canis lupus familiaris }\end{array}$ & $98 \%$ match \\
\hline B7 & $\checkmark$ & Felis silvestris catus & $100 \%$ match \\
\hline
\end{tabular}

Species identification of fur samples and percentage of similarity after research conducted using the BLAST tool. $\checkmark$ success in obtaining the consensus sequence; $=$ failure in obtaining the consensus sequence.

the $16 S$ marker, only 4 samples out of 12 were successfully amplified, probably as a result of the larger fragment size (244 bp, in contrast with the $150 \mathrm{bp}$ of the $12 S$ ), as shown in Table 6. The PCR products were cloned and 20 colonies were sequenced for each of them, to detect possible nucleotide misincorporations or

Table 6 Results of 165 marker analysis

\begin{tabular}{|c|c|c|c|}
\hline $\begin{array}{l}\text { Sample } \\
\text { name }\end{array}$ & $\begin{array}{l}16 S \text { consensus } \\
\text { sequence }\end{array}$ & Identified species & $\begin{array}{l}\text { Percentage } \\
\text { of similarity }\end{array}$ \\
\hline $\mathrm{A} 1$ & $\checkmark$ & Canis lupus familiaris & $99 \%$ match \\
\hline$A 2$ & $\checkmark$ & Canis lupus familiaris & $99 \%$ match \\
\hline A3 & $\checkmark$ & Homo sapiens & $95 \%$ match \\
\hline A4 & $=$ & Not available & \\
\hline A5 & $=$ & Not available & \\
\hline B1 & $=$ & Not available & \\
\hline B2 & $\checkmark$ & Homo sapiens & $95 \%$ match \\
\hline B3 & $=$ & Not available & \\
\hline B4 & $=$ & Not available & \\
\hline B5 & $=$ & Not available & \\
\hline B6 & $=$ & Not available & \\
\hline B7 & $=$ & Not available & \\
\hline
\end{tabular}

Species identification of fur samples and percentage of similarity after research conducted using the BLAST tool. $\checkmark$ success in obtaining the consensus sequence; $=$ failure in obtaining the consensus sequence. 
contaminations. To identify the species, the consensus sequence produced for each sample was compared with the NCBI database on GenBank. A great many sequences are held on the GenBank database and even if a complete match cannot be found, a BLAST search allows identification of possibly closely related species, providing information at the level of the genus or family. The results obtained from this search and the percentage of similarity between the fur samples and the NCBI references for each marker analyzed are summarized in Table 5 and Table 6.

Probably as a result of contamination by human genetic material from those who treated or handled the furs, which was not entirely eliminated during the cleaning of the samples, the consensus sequence obtained from samples A5, B1, B2 and B3 (12S marker) and A3 and B2 (16S marker) showed a 93 to $95 \%$ degree of similarity to the reference sequence for Homo sapiens. A match with $100 \%$ of homology between the short $12 S$ fragment (150 bp) from the B7 sequence (Figure 10) and the NCBI reference of Felis silvestris catus was observed. This complete degree of homology could be explained as follows: either the sample comes from the species with which it matches or, because of the shortness of the sequence fragment, the sample matches that NCBI reference by chance and comes from an unknown species in GenBank. Furthermore, a search on GenBank for a comparison with sequences belonging to different Felis species or subspecies returned results only for the domestic species concerning this genetic marker. Owing to the availability of this short DNA sequence and the lack of knowledge about the variability between different species or subspecies for the $12 S$ fragment, no phylogenetic analysis was performed for this sample and the genus Felis. For these reasons, it was not possible to attribute the hair solely to the domestic subspecies.

The $12 S$ consensus sequences of samples A1, A3, A4 and B6 (Figure 10) were identical to each other, as was the sequence for the $16 S$ in samples A1 and
A2 (Figure 11), presumably because the hair analyzed belonged to the same species. Only the $12 \mathrm{~S}$ consensus sequence of sample A2 showed a transversion ( $\mathrm{T}$ instead of $\mathrm{A}$ ) when compared with the other samples analyzed (Figure 10). The 98\% homology between these sequences and NCBI references of Canis lupus laniger, Canis lupus chanco and Canis lupus familiaris was observed and could be explained in two ways. Either the unknown samples came from one of these species and the differences were due to intraspecific variation, or they came from an unknown but closely related species that was not present on the database.

To obtain an unambiguous attribution of the hair to the subspecies listed, and distinguish the fur samples from potential different individuals, the analysis focused on the study of the HVS-I of the canine D-loop. The amplification of HVS-I using seven overlapping fragments (Figure 12) led to a complete consensus sequence for samples A1 and A2. For samples A3, A4 and B6, the amplification of the IV fragment (150 bp) failed, maybe because of degradation phenomena with possible modification in the annealing site of the primers. However, it is most likely that the failure to obtain a result could be explained by the presence of mutations in the DNA template that prevented the annealing of one or both of the two primers. The complete consensus sequences of A1 and A2 samples were aligned with each other and with the partial consensus sequences of samples A3, A4 and B6. All consensus sequences are available at the National Center for Biotechnology [GeneBank Accession Numbers: KJ828711-KJ828715]. The sequences were similar but not the same (Figure 13). Owing to the large variability of the genetic region analyzed, we presumed that the hair could have belonged to different individuals. Both the complete consensus sequences of samples A1 and A2 and the partial ones of A3, A4 and B6 were compared with those held on GenBank. The results obtained showed a homology of $97 \%$ to $99 \%$ with Nyctereutes procyonoides. The degree of match was not 100\%

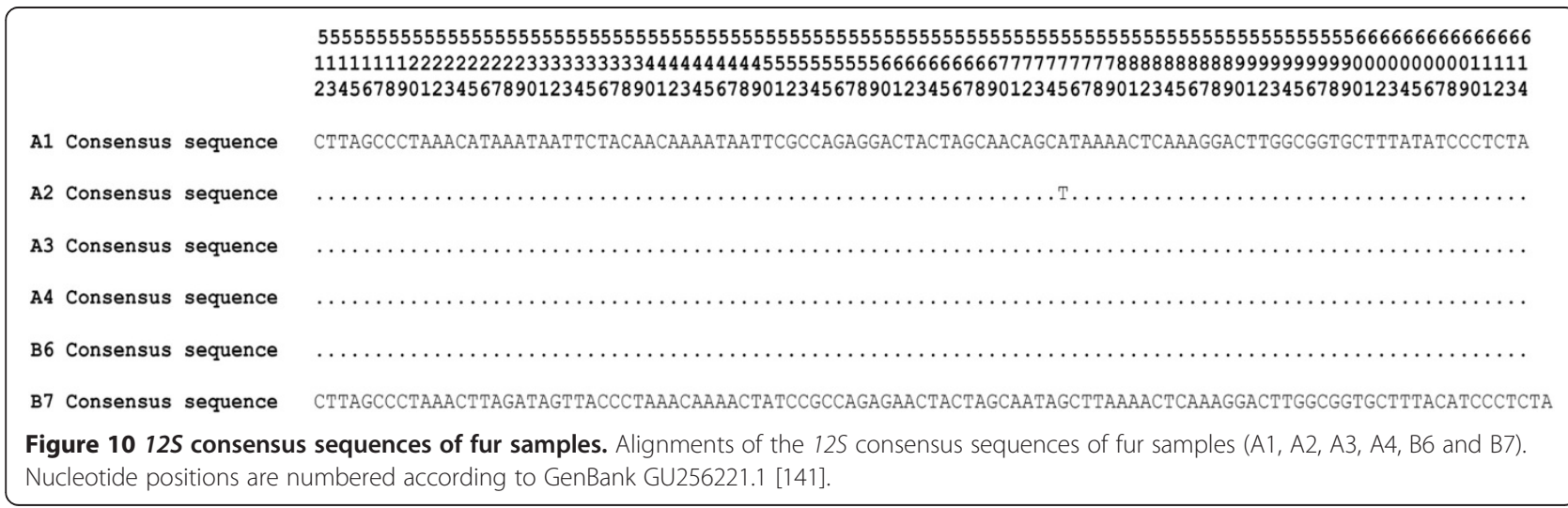




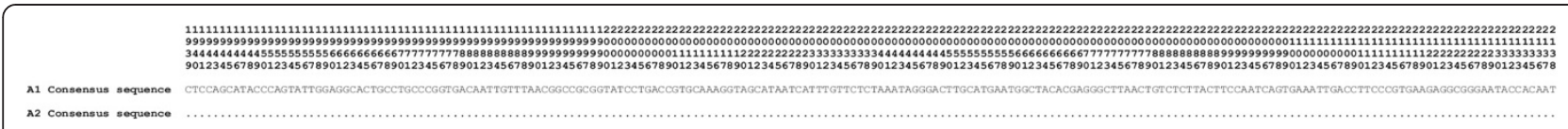

Figure $1116 \mathrm{~S}$ consensus sequence of fur samples. Alignments of the 165 consensus sequences of fur samples (A1 and A2). Nucleotide positions are numbered according to GenBank GU256221.1 [141].

and this could be explained in the following ways: (1) different individuals of the same species could have different genetic profiles because the marker analyzed was a highly variable region; (2) some of the differences observed between unknown and reference samples were the result of post mortem damage [112,142,143], that is, the modifications in DNA sequence arose subsequent to cell death or as a result of the tanning process. The apparent inconsistency found when analyzing the results of mtDNA (12S, $16 S$ and HVS-I) can be explained by the small amount of data available in the literature on the genome of Nyctereutes procyonoides and, at the time of the realization of this work, by the absence of the $12 S$ sequence of this species in the NCBI database. Therefore, the most likely diagnosis of the species was that of the Nyctereutes procyonoides, the raccoon dog. This conclusion was confirmed when the $12 S$ sequence of the Nyctereutes procyonoides genome was published in GenBank.

The next comparison of the $12 S$ consensus sequence of samples A1, A2, A3, A4 and B6 with those held on GenBank showed the highest homology (100\%) with Nyctereutes procyonoides for samples A1, A3, A4 and B6 and $99 \%$ homology with the same species for sample A2. The next comparison of the consensus sequence for $16 \mathrm{~S}$ of samples A1 and A2 showed the highest homology (100\%) with Nyctereutes procyonoides. These data confirmed the information obtained from the HVS-I. Several sequences (280 for the $12 S$ marker and 1,186 for the HVS-I) from the NCBI database relative to all species or subspecies that showed a homology of almost

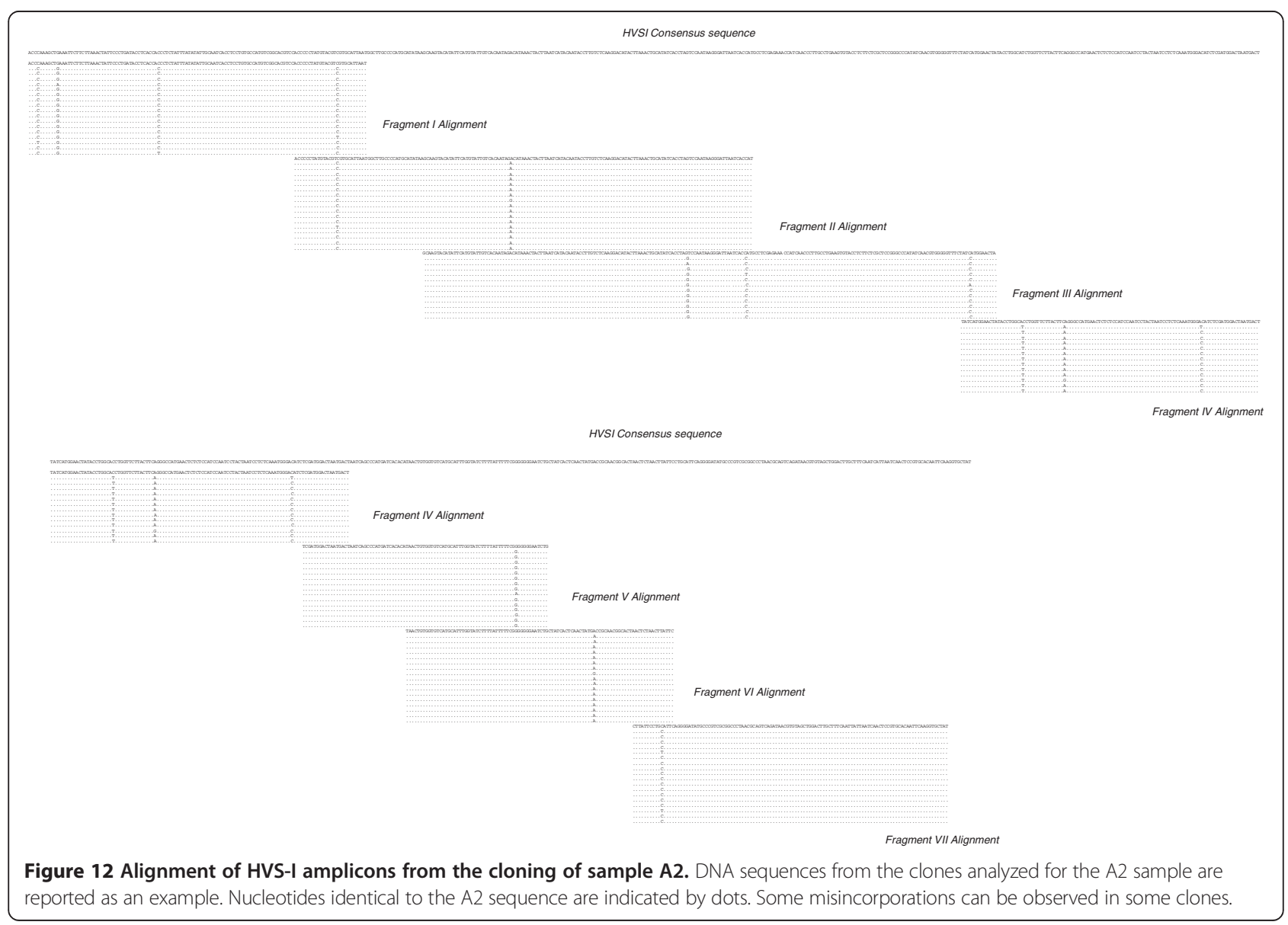



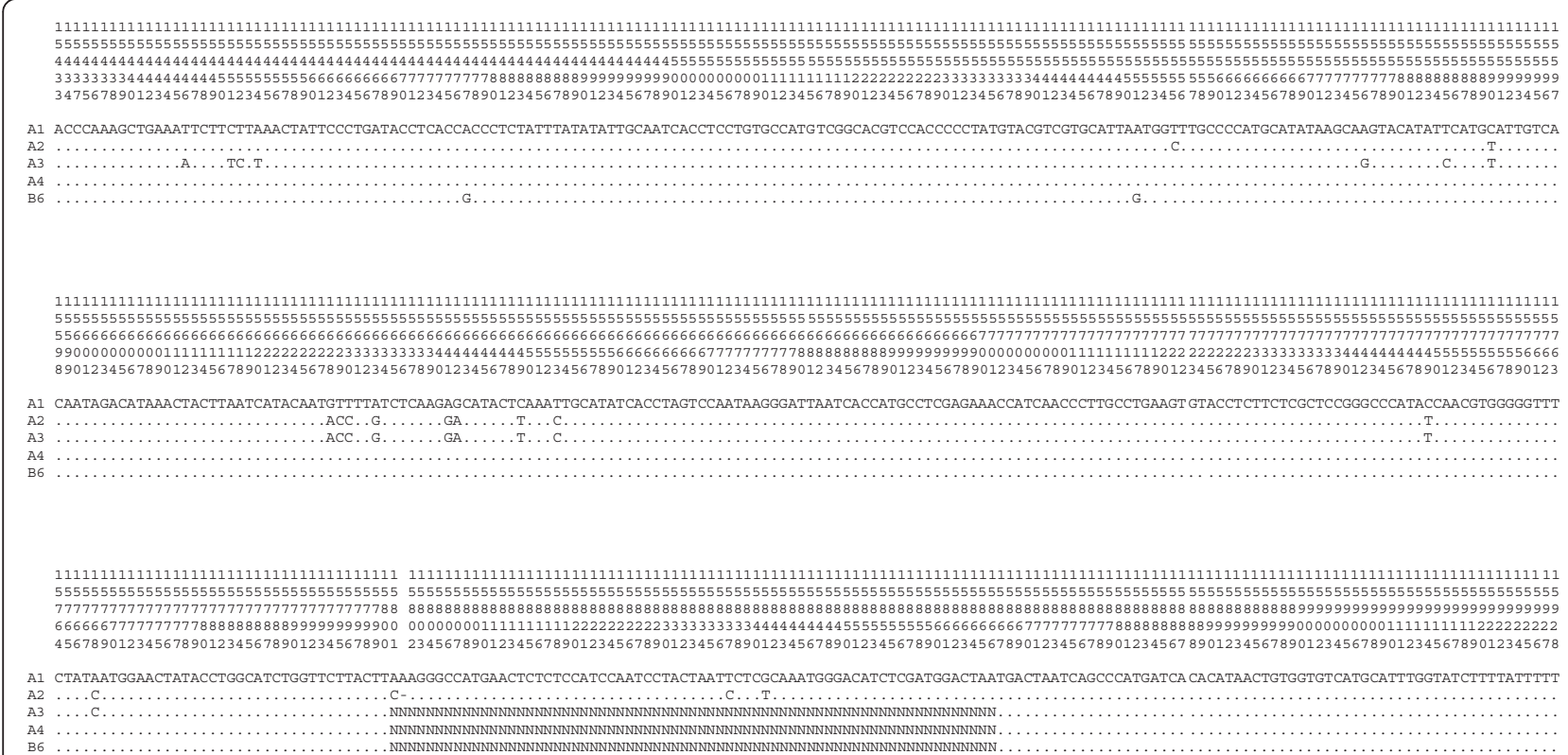

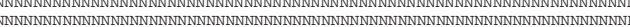

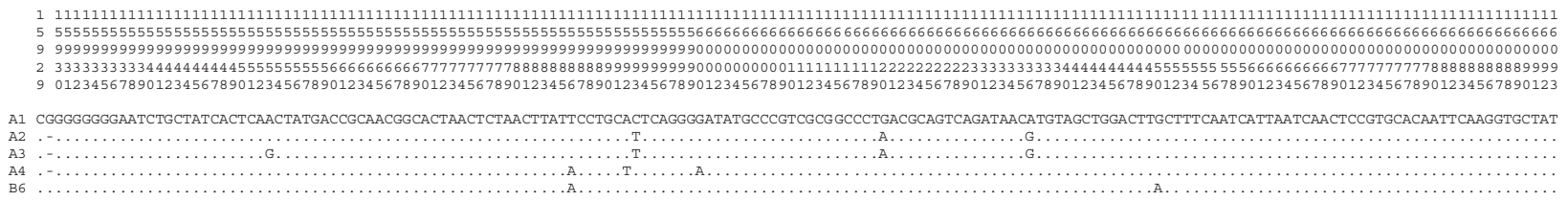

Figure 13 HVS-I consensus sequences of fur samples. Alignments of the HVS-I consensus sequences of fur samples (A1, $A 2, A 3, A 4$ and $B 6)$. The numbering of the nucleotide positions is at the top, according to GenBank GU256221.1 [141]. Nucleotides identical to the A1 sequence are indicated by dots.

98\% with fur samples were collected in a dataset (Table 7). To better investigate how the fur samples fell into the genetic variability of the comparison dataset, phylogenetic analyses were performed. The neighbourjoining tree for the $12 S$ marker (Figure 14) was calculated using the Kimura two-parameter model [144]: this described the substitution pattern in the dataset of sequences better than other available models. Genera Canis and Nyctereutes were separated into two groups with a bootstrap value of $79 \%$. The three available sequences of Canis lupus chanco were distributed as follows: one in the subgroup of Canis lupus and Canis lupus familiaris, and the others in that of Canis lupus laniger. All fur samples fell into the same group of $\mathrm{Nyc}$ tereutes procyonoides but the three NCBI reference sequences differed from ours. The neighbour-joining tree obtained from the alignment between the HVS-I consensus sequences of the fur samples and the comparison dataset is shown in Figure 15. The tree was calculated using the Tamura three-parameter model of pairwise base substitution [145]. This was the best model to describe sequence divergence in the dataset. Overall groupings of the sequences in the dataset were as expected: genera Canis and Nyctereutes were separated into two groups, with the maximum value of statistical support. A $100 \%$ bootstrap value at the node connecting these genera indicated that the genetic marker (HVS-I) we used had enough informative power to make the two groups distinguishable.

In the genus Canis, some sequences of Canis lupus chanco cluster together with Canis lupus and Canis lupus familiaris, while others belong to the same group of Canis lupus laniger. Consensus sequences of the fur samples fell clearly into the variability of the Nyctereutes procyonoides group. The phylogenetic analysis confirmed the indications given by the BLAST search, showing samples A1, A2, A3, A4 and B6 as belonging to the Nyctereutes procyonoides species. Although Nyctereutes procyonoides is often confused with raccoons and badgers, it does not belong to the Procyonidae family but to the Canidae, as does the domestic dog. Nyctereutes procyonoides and the domestic dog present the genus they belong to: the raccoon dog actually belongs to the genus Nyctereutes, while the domestic dog 
Table 7 Number of sequences and their origin for the dataset used in the phylogenetic analysis

\begin{tabular}{|c|c|c|}
\hline Species & $\begin{array}{l}\text { Number of } \\
\text { sequences }\end{array}$ & GenBank accession numbers \\
\hline \multirow[t]{4}{*}{ Canis lupus } & \multirow[t]{4}{*}{37} & AF005296-005314, \\
\hline & & AF008135-008142, \\
\hline & & AF008160-008167 [146] \\
\hline & & AY240073, AY240155 [125] \\
\hline \multirow[t]{20}{*}{ Canis lupus familiaris } & \multirow[t]{20}{*}{1,111} & NC002008, U96639* [127] \\
\hline & & EU223385-223811 [147] \\
\hline & & AY656703-656710 [148] \\
\hline & & AY656737-656755* [149] \\
\hline & & EU816456-816557 [150] \\
\hline & & AF531654-531741, \\
\hline & & HQ261490 [151] \\
\hline & & AF005280-005295, \\
\hline & & AF008143-008157, \\
\hline & & AF008168-008182 [146] \\
\hline & & $J$ JF342807-342906 * [152] \\
\hline & & AY240030-240072, \\
\hline & & AY240074-240093, \\
\hline & & AY240095-240154, \\
\hline & & AY2400156-2400157 [125] \\
\hline & & AF064569-064586 [153] \\
\hline & & EF122413-122428 [94] \\
\hline & & AB622516-622568, \\
\hline & & AB700664-700665 [154] \\
\hline & & EU789667-789786** [150] \\
\hline \multirow[t]{2}{*}{ Canis lupus laniger } & \multirow[t]{2}{*}{3} & KF573616* [155] \\
\hline & & NC011218, FJ032363* [156] \\
\hline \multirow[t]{7}{*}{ Canis lupus chanco } & \multirow[t]{7}{*}{42} & AB007375-007379 [157] \\
\hline & & AB480743-480744 [158] \\
\hline & & AY333738-333742 [159] \\
\hline & & EU442884* [160] \\
\hline & & GQ374438* [141] \\
\hline & & JX415343-415379 [161] \\
\hline & & NC010340* [156] \\
\hline \multirow[t]{10}{*}{ Nyctereutes procyonoides } & \multirow[t]{10}{*}{113} & AB292740 [162] \\
\hline & & D83614-83615 [163] \\
\hline & & EU642411-642457 [164] \\
\hline & & FJ888513-888521 [165] \\
\hline & & JF809819-809848 [166] \\
\hline & & KC344215-344235, \\
\hline & & KC509604 [167] \\
\hline & & GU256221* [141] \\
\hline & & NC013700* [168] \\
\hline & & KF781340** [169] \\
\hline
\end{tabular}

All sequences reported in the table were used for HVS-I comparison. Those marked with * were used both for HVS-I and 125 and those marked with ** were used only for 125 comparison. belongs to the genus Canis. The physical characteristics of the raccoon dog are substantially similar to those of a medium-sized domestic dog with the indicative feature of a raccoon snout, although it is distinguished taxonomically from the raccoon itself. Nyctereutes comes from Japan, Siberia and Manchuria.

\section{Conclusions}

Macroscopic and microscopic analysis allowed confirmation of the hypothesis regarding the analyzed hair belonging to real animals, although it failed to provide any kind of certainty regarding the actual family or species. The sequence data and the comparisons with the samples held on GenBank showed that, in most cases, the hair belonged to the Canidae family, and in only one case to Felidae. The genetic data related to the diagnosis of the genus and the species of Canidae hair was heterogeneous: the sequence results of samples A1, A2, A3, A4 and B6 (12S, $16 S$ and HVS-I) showed a high homology with the genus Canis and the genus Nyctereutes (raccoon dog). This initial uncertainty led obviously to a likely ambiguous diagnosis of the species that was impossible to predict. However, the genetic results confirmed a unique diagnosis of nonattribution for the protected subspecies Canis lupus familiaris. Despite previous reservations advanced, the species that appeared more consistent with the data obtained from the BLAST search was Nyctereutes procyonoides, and phylogenetic analysis confirmed this observation.

The data of the diagnosis of the genus and the species of the hair belonging to the Felidae family appeared homogeneous. The study revealed a high similarity between our sequences and the genus Felis, species Felis silvestris. However, the failure to diagnose a single domestic subspecies (Felis silvestris catus) was mainly due to the limited amount of genetic data for comparative purposes in the literature. In fact, no information on the genetic differences between the various subspecies and on the process of cat domestication [170,171] are known and no genetic data are available on GenBank for different subspecies of Felis silvestris regarding the $12 S$ marker. For these reasons, an unambiguous attribution of one of the fur samples to the subspecies Felis silvestris catus was not possible. Finally, we would like to add that beyond scientific classification, prohibition of the use for commercial purposes should not be just confined to the subspecies Canis lupus familiaris or Felis silvestris catus but should be extended to other Canidae and Felidae, particularly when taking into account sociocultural practices and geographical regions far from the West. 


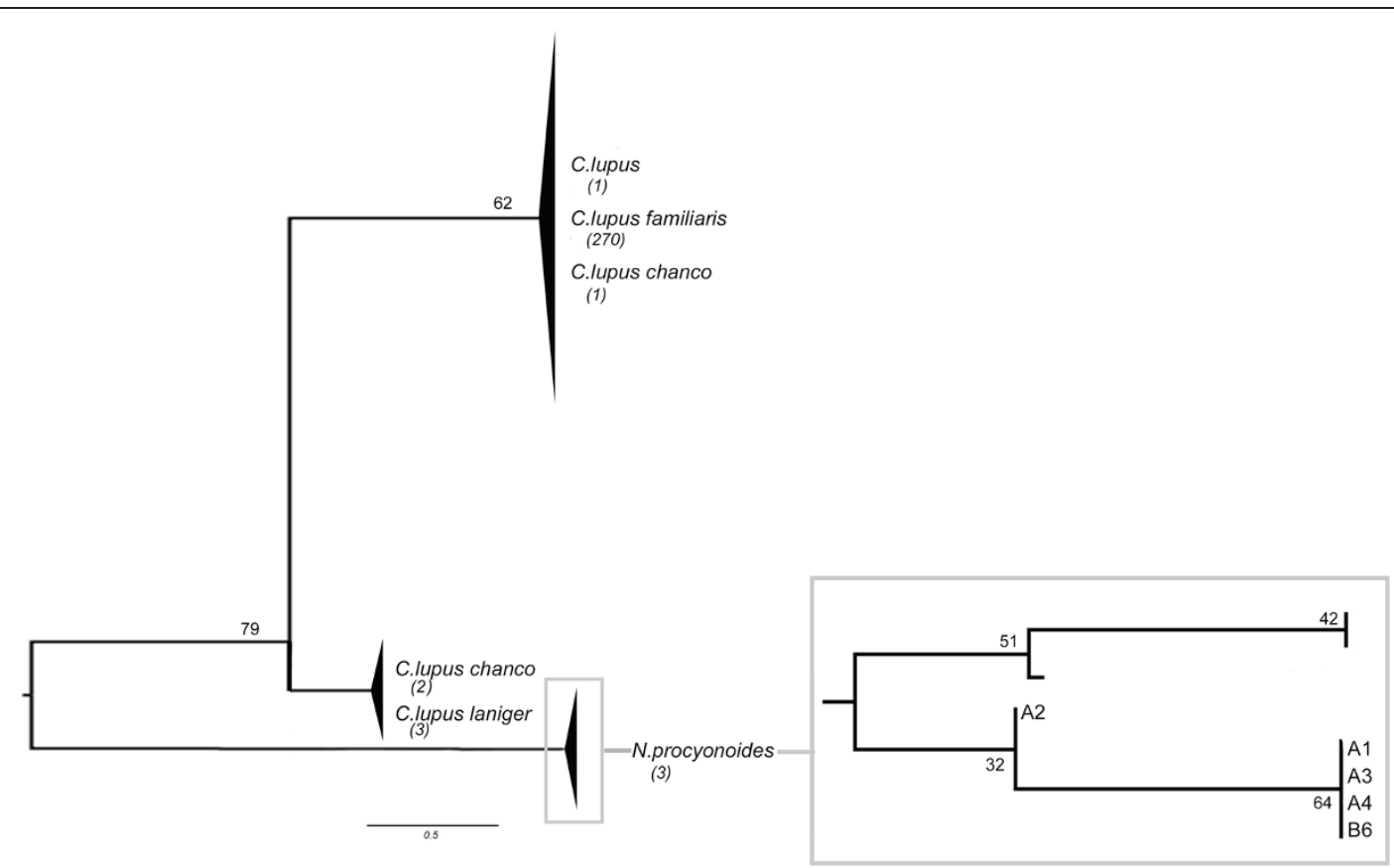

Figure 14 Neighbour-joining tree built for 125 marker. The bootstrap neighbour-joining tree inferred from 1,000 replicates represents the evolutionary history of 285 sequences ( $280 \mathrm{NCBI}$ reference sequences and five fur samples) of the 125 marker. The reference sequences were retrieved from the species that presented almost $98 \%$ of similarity to the sequences obtained from fur samples $A 1, A 2, A 3, A 4$ and B6. The bootstrap percentage values are indicated at the nodes. In each clade, the number of comparison sequences is indicated below the name of the species. The Nyctereutes procyonoides clade is enlarged for better visibility within the grey box.

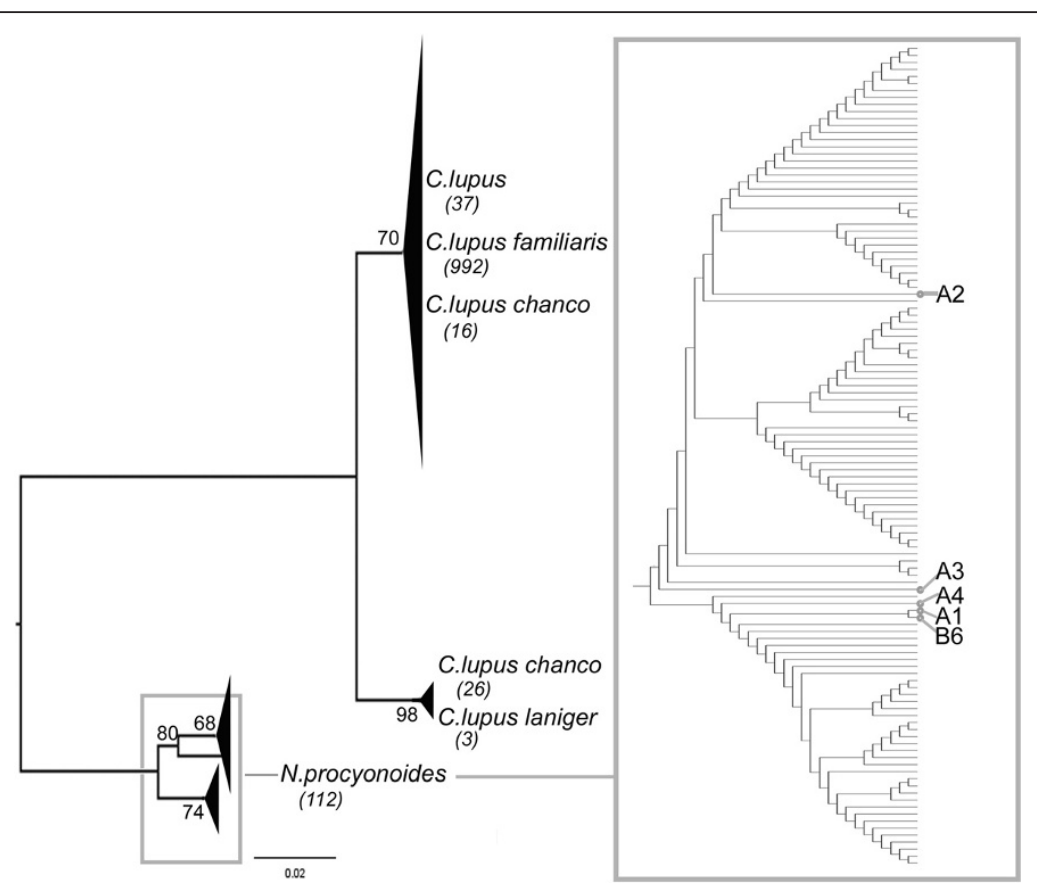

Figure 15 Neighbour-joining tree built for HVS-I. The bootstrap neighbour-joining tree inferred from 1,000 replicates represents the evolutionary history of 1,191 sequences (1,186 NCBI reference sequences and five fur samples) of the HVS-I marker. The reference sequences were retrieved from the species that presented almost $98 \%$ of similarity to the sequences obtained from fur samples $A 1, A 2, A 3, A 4$ and $B 6$. The bootstrap percentage values are indicated at the nodes whenever larger than 50. In each clade, the number of comparison sequences is indicated below the name of the species. The Nyctereutes procyonoides clade is enlarged for better visibility within the grey box. This subtree is condensed for bootstrap values lower than 50 and only topology is shown. The position of the fur samples is indicated by grey dots linked to the name of the sample. 


\section{Abbreviations}

BLAST: Basic Local Alignment Search Tool; bp: base pair; COl: cytochrome c oxidase subunit 1; dNTP: deoxy-nucleotide-triphosphate; HVS: hypervariable segment; HVS-I: hypervariable segment I; HVS-II: hypervariable segment II; mtDNA: mitochondrial DNA; NDH: nicotinamide adenine dinucleotide nt: nucleotide; PCR: polymerase chain reaction; SDS: sodium dodecyl sulphate; VNTR: variable number tandem repeat.

\section{Competing interests}

The authors declare that they have no competing interests.

\section{Authors' contributions}

EP conceived and designed the experiments. EP, RC, AV and GD performed the experiments. EP, RC and SV analyzed the data. FB, AB, GL and DC contributed reagents, materials and analysis tools. EP wrote the paper. All authors read and approved the final manuscript.

\section{Acknowledgements}

We are very grateful to Jacopo Marconcini for providing language support during the drafting of our paper and Claire Stypulkowski for invaluable advice in proofreading the article.

\section{Author details}

'Dipartimento di Biologia, Università di Firenze, via del Proconsolo 12, 50122 Florence, Italy. ${ }^{2}$ Reparto Carabinieri Investigazioni Scientifiche di Roma, Sezione di Chimica, viale Tor di Quinto 119, Rome, Italy. ${ }^{3}$ Istituto Superiore di Tecniche Investigative dei Carabinieri, viale Salvo D'Acquisto 2, 00049 Velletri (Roma), Italy. ${ }^{4}$ Reparto Carabinieri Investigazioni Scientifiche di Roma, Sezione di Biologia, viale Tor di Quinto 119, Rome, Italy. ${ }^{5}$ Reparto Carabinier Investigazioni Scientifiche di Parma, Parco Ducale 3, Parma, Italy.

Received: 30 January 2014 Accepted: 29 April 2014

Published: 2 June 2014

\section{References}

1. Butler JM: Non-human DNA. In Advanced Topics in Forensic DNA Typing Methodology. Edited by Butler JM. London: Academic; 2011:473-487.

2. Barbanera F, Guerrini M, Beccani $C$, Forcina $G$, Anayiotos $P$, Panayides P: Conservation of endemic and threatened wildlife: molecular forensic DNA against poaching of the Cypriot mouflon (Ovis orientalis ophion, Bovidae). Forensic Sci Int Genet 2012, 6:671-675.

3. Berger C, Berger B, Parson W: Sequence analysis of the canine mitochondrial DNA control region from shed hair samples in criminal investigations. Methods Mol Biol 2012, 830:331-348.

4. Allgeier L, Hemenway J, Shirley N, LaNier T, Coyle HM: Field testing of collection cards for Cannabis sativa samples with a single hexanucleotide DNA marker. J Forensic Sci 2011, 56:1245-1249.

5. Butler JM, Schneider PM, Carracedo A: Journal update. Forensic Sci Int Genet 2010, 4:143-144

6. Yi-Ming $L$, Zenxiang $G$, Xinhai $L$, Sung $W$, Niemelä J: Illegal wildlife trade in the Himalayan region of China. Biodivers Conserv 2000, 9:901-918.

7. Wilson-Wilde L: Combating wildlife crime. Forensic Sci Med Pathol 2010 6:149-150

8. Wilson-Wilde L: Wildlife crime: a global problem. Forensic Sci Med Pathol 2010, 6:221-222

9. Alacs EA, Georges A, FitzSimmons NN, Robertson J: DNA detective: a review of molecular approaches to wildlife forensics. Forensic Sci Med Pathol 2010, 6:180-194.

10. World Wildlife Fund: Tiger. [https://worldwildlife.org/species/tiger]

11. World Wildlife Fund: Elephant. [https://worldwildlife.org/species/elephant]

12. Wozney KM, Wilson PJ: Real-time PCR detection and quantification of elephantid DNA: species identification for highly processed samples associated with the ivory trade. Forensic Sci Int 2012, 219:106-112.

13. Peppin L, McEwing R, Carvalho GR, Ogden R: A DNA-based approach for the forensic identification of Asiatic black bear (Ursus thibetanus) in a traditional Asian medicine. J Forensic Sci 2008, 53:1358-1362.

14. Dubey B, Meganathan PR, Haque I: DNA mini-barcoding: an approach for forensic identification of some endangered Indian snake species. Forensic sci Med Pathol 2011, 5:181-184.
15. Meganathan PR, Dubey B, Jogayya KN, Haque I: Validation of a multiplex PCR assay for the forensic identification of Indian crocodiles. J Forensic Sci 2011, 56:1241-1244.

16. Reid BN, LE M, McCord WP, Iverson JB, Georges A, Bergmann T, Amato G, Desalle R, Naro-Maciel E: Comparing and combining distance-based and character-based approaches for barcoding turtles. Mol Ecol Resour 2011, 11:956-967.

17. Rosen GE, Smith KF: Summarizing the evidence on the international trade in illegal wildlife. Ecohealth 2010, 7:24-32.

18. Nijman V: An overview of international wildlife trade from Southeast Asia. Biodivers Conserv 2009, 19:1101-1114.

19. Alacs $E$, Georges A: Wildlife across our borders: a review of the illegal trade in Australia. Aust J Forensic Sci 2008, 40:147-160.

20. Coghlan ML, White NE, Parkinson L, Haile J, Spencer PBS, Bunce M: Egg forensics: an appraisal of DNA sequencing to assist in species identification of illegally smuggled eggs. Forensic Sci Int Genet 2012, 6:268-273.

21. Lee JC-I, Hsieh H-M, Huang L-H, Kuo Y-C, Wu J-H, Chin S-C, Lee A-H, Linacre $A$, Tsai L-C: Ivory identification by DNA profiling of cytochrome $b$ gene. Int J Legal Med 2009, 123:117-121.

22. Comstock KE, Ostrander EA, Wasser SK: Amplifying nuclear and mitochondrial DNA from African elephant ivory: a tool for monitoring the ivory trade. Conserv Biol 2003, 17:1840-1843.

23. Gupta S, Thangaraj K, Singh L: A simple and inexpensive molecular method for sexing and identification of the forensic samples of elephant origin. J Forensic Sci 2006, 51:805-807.

24. Wasser SK, Clark B, Laurie C: The ivory trail. Sci Am 2009, 301:68-74. 76.

25. Wasser SK, Joseph Clark W, Drori O, Stephen Kisamo E, Mailand C, Mutayoba B, Stephens M: Combating the illegal trade in African elephant ivory with DNA forensics. Conserv Biol 2008, 22:1065-1071.

26. Biscardi B, Welsh W, Kennedy A: Discrimination of the hard keratins animal horn and chelonian shell using attenuated total reflection-infrared spectroscopy. App/ Spectrosc 2012, 66:606-608.

27. Parlamento Italiano: Disposizioni concernenti il divieto di maltrattamento degli animali, nonché di impiego degli stessi in combattimenti clandestini o competizioni non autorizzate. [http://www.camera.it/parlam/leggi/04189l.htm]

28. Bisbing RE: Hair comparison: microscopic. In Encyclopedia of Forensic Science, Volume 3. Edited by Siegel J, Knupfer G, Saukko P. London: Academic; 2000:1002-1016.

29. Simon C, Buckley TR, Frati F, Stewart JB, Beckenbach AT: Incorporating molecular evolution into phylogenetic analysis, and a new compilation of conserved polymerase chain reaction primers for animal mitochondrial DNA. Annu Rev Ecol Evol Syst 2006, 37:545-579.

30. Clayton DA: Replication of animal mitochondrial DNA. Cell 1982, 28:693-705.

31. Hayashi J, Tagashira Y, Yoshida MC: Absence of extensive recombination between inter- and intraspecies mitochondrial DNA in mammalian cells. Exp Cell Res 1985, 160:387-395.

32. Robin ED, Wong R: Mitochondrial DNA molecules and virtual number of mitochondria per cell in mammalian cells. J Cell Physiol 1988, 136:507-513.

33. Pfeiffer $\mathrm{H}$, Benthaus $\mathrm{S}$, Rolf $\mathrm{B}$, Brinkmann B. The Kaiser's tooth. Int J Legal Med 2003, 117:118-120.

34. Ginther $C$, Issel-Tarver L, King MC: Identifying individuals by sequencing mitochondrial DNA from teeth. Nat Genet 1992, 2:135-138

35. Loreille OM, Diegoli TM, Irwin JA, Coble MD, Parsons TJ: High efficiency DNA extraction from bone by total demineralization. Forensic Sci Int Genet 2007, 1:191-195.

36. Anslinger K, Weichhold G, Keil W, Bayer B, Eisenmenger W: Identification of the skeletal remains of Martin Bormann by mtDNA analysis. Int J Legal Med 2001, 114:194-196.

37. Budowle B, van Daal A: Forensically relevant SNP classes. Biotechniques 2008, 44:603-608. 610

38. Parson W: Relevance of mtDNA analysis for forensic applications. Rechtmedizin 2009, 19:183-192.

39. Allen $M$, Engström AS, Meyers $S$, Handt $O$, Saldeen T, von Haeseler A, Pääbo S, Gyllensten U: Mitochondrial DNA sequencing of shed hairs and saliva on robbery caps: sensitivity and matching probabilities. J Forensic Sci 1998, 43:453-464.

40. Brown WM, George M, Wilson AC: Rapid evolution of animal mitochondrial DNA. Proc Natl Acad Sci U S A 1979, 76:1967-1971.

41. Kuwayama R, Ozawa T: Phylogenetic relationships among European red deer, wapiti, and sika deer inferred from mitochondrial DNA sequences. Mol Phylogenet Evol 2000, 15:115-123. 
42. Irwin DM, Kocher TD, Wilson AC: Evolution of the cytochrome $b$ gene of mammals. J Mol Evol 1991, 32:128-144.

43. Kocher TD, Thomas WK, Meyer A, Edwards SV, Pääbo S, Villablanca FX, Wilson AC: Dynamics of mitochondrial DNA evolution in animals: amplification and sequencing with conserved primers. Proc Natl Acad SC U S A 1989, 86:6196-6200.

44. Tobe SS, Linacre A: A method to identify a large number of mammalian species in the UK from trace samples and mixtures without the use of sequencing. Forensic Sci Int Genet Supp/ Ser 2008, 1:625-627.

45. An J, Lee $M-Y$, Min M-S, Lee M-H, Lee H: A molecular genetic approach for species identification of mammals and sex determination of birds in a forensic case of poaching from South Korea. Forensic Sci Int 2007, 167:59-61.

46. Tobe S, Linacre A: Species identification of human and deer from mixed biological material. Forensic Sci Int 2007, 169:278-279.

47. De Pancorbo MM, Castro A, Fernandez-Fernandez I, Gonzalez-Fernandez M, Martnez-Bouzas C, Cuevas N: Cytochrome $b$ and HVI sequences of mitochondrial DNA to identify domestic animal hair in forensic casework. Int Congr Ser 2003, 1239:841-845

48. Wan Q-H, Fang S-G: Application of species-specific polymerase chain reaction in the forensic identification of tiger species. Forensic Sci Int 2003, 131:75-78.

49. Wetton JH, Tsang CSF, Roney CA, Spriggs AC: An extremely sensitive species-specific ARMs PCR test for the presence of tiger bone DNA Forensic Sci Int 2004, 140:139-145.

50. Tobe SS, Linacre A: Identifying endangered species from degraded mixtures at low levels. Forensic Sci Int Genet Supp/ Ser 2009, 2:304-305.

51. Moore MK, Bemiss JA, Rice SM, Quattro JM, Woodley CM: Use of restriction fragment length polymorphisms to identify sea turtle eggs and cooked meats to species. Conserv Genet 2003, 4:95-103.

52. Hsieh H-M, Huang L-H, Tsai L-C, Liu C-L, Kuo Y-C, Hsiao C-T, Linacre A, Lee $J C-I$ : Species identification of Kachuga tecta using the cytochrome $b$ gene. J Forensic Sci 2006, 51:52-56.

53. Rohilla MS, Tiwari PK: Restriction fragment length polymorphism of mitochondrial DNA and phylogenetic relationships among five species of Indian freshwater turtles. J App/ Genet 2008, 49:167-182

54. Meganathan PR, Dubey B, Haque I: Molecular identification of crocodile species using novel primers for forensic analysis. Conserv Genet 2008, 10:767-770.

55. Hsieh H-M, Huang L-H, Tsai L-C, Kuo Y-C, Meng H-H, Linacre A, Lee JC-I: Species identification of rhinoceros horns using the cytochrome $b$ gene. Forensic Sci Int 2003, 136:1-11.

56. Gupta SK, Verma SK, Singh L: Molecular insight into a wildlife crime: the case of a peafowl slaughter. Forensic Sci Int 2005, 154:214-217.

57. Barcode of Life Data Systems. [http:www.boldsystems.org]

58. Hebert PDN, Cywinska A, Ball SL, de Waard JR: Biological identifications through DNA barcodes. Proc Biol Sci 2003, 270:313-321.

59. Borisenko AV, Lim BK, Ivanova NV, Hanner RH, Hebert PDN: DNA barcoding in surveys of small mammal communities: a field study in Suriname. Mol Ecol Resour 2008, 8:471-479.

60. Hebert PDN, Ratnasingham S, De Waard JR: Barcoding animal life: cytochrome $c$ oxidase subunit 1 divergences among closely related species. Proc Biol Sci 2003, 270(Suppl 1):S96-S99.

61. Meier R, Shiyang K, Vaidya G, Ng PKL: DNA barcoding and taxonomy in Diptera: a tale of high intraspecific variability and low identification success. Syst Biol 2006, 55:715-728.

62. Hajibabaei M, Janzen DH, Burns JM, Hallwachs W, Hebert PDN: DNA barcodes distinguish species of tropical Lepidoptera. Proc Natl Acad Sci U S A 2006, 103:968-971.

63. Santos Rojo Velasco GS: Testing molecular barcodes: invariant mitochondrial DNA sequences vs the larval and adult morphology of West Palaearctic Pandasyopthalmus species (Diptera: Syrphidae: Paragini). Eur J Entomol 2006, 103:443-458.

64. Smith MA, Woodley NE, Janzen DH, Hallwachs W, Hebert PDN: DNA barcodes reveal cryptic host-specificity within the presumed polyphagous members of a genus of parasitoid flies (Diptera: Tachinidae). Proc Natl Acad Sci U S A 2006, 103:3657-3662.

65. Cywinska A, Hunter FF, Hebert PDN: Identifying Canadian mosquito species through DNA barcodes. Med Vet Entomol 2006, 20:413-424.

66. Nelson LA, Wallman JF, Dowton M: Using COI barcodes to identify forensically and medically important blowflies. Med Vet Entomol 2007, 21:44-52.

67. Mitchell A: DNA barcoding demystified. Aust J Entomol 2008, 47:169-173.
68. Smith MA, Poyarkov NA, Hebert PDN: DNA barcoding: CO1 DNA barcoding amphibians: take the chance, meet the challenge. Mol Ecol Resour 2008, 8:235-246.

69. Holmes BH, Steinke D, Ward RD: Identification of shark and ray fins using DNA barcoding. Fish Res 2009, 95:280-288.

70. Hebert PDN, Stoeckle MY, Zemlak TS, Francis CM: Identification of birds through DNA barcodes. PLOS Biol 2004, 2:e312.

71. Yoo HS, Eah J-Y, Kim JS, Kim Y-J, Min M-S, Paek WK, Lee H, Kim C-B: DNA barcoding Korean birds. Mol Cells 2006, 22:323-327.

72. Tavares ES, Baker AJ: Single mitochondrial gene barcodes reliably identify sister-species in diverse clades of birds. BMC Evol Biol 2008, 8:81.

73. Lohman DJ, Prawiradilaga DM, Meier R: Improved COI barcoding primers for Southeast Asian perching birds (Aves: Passeriformes). Mol Ecol Resou 2009, 9:37-40.

74. Wong EH-K, Shivji MS, Hanner RH: Identifying sharks with DNA barcodes: assessing the utility of a nucleotide diagnostic approach. Mol Ecol Resou 2009, 9(Suppl s1):243-256.

75. Huang J, Xu Q, Sun ZJ, Tang GL, Su ZY: Identifying earthworms through DNA barcodes. Pedobiologia (Jena) 2007, 51:301-309.

76. Dalton DL, Kotze A: DNA barcoding as a tool for species identification in three forensic wildlife cases in South Africa. Forensic Sci Int 2011, 207:e51-e54.

77. Guo H, Wang W, Yang N, Guo B, Zhang S, Yang R, Yuan Y, Yu J, Hu S, Sun Q, Yu J: DNA barcoding provides distinction between Radix Astragali and its adulterants. Sci China Life Sci 2010, 53:992-999.

78. Tyagi A, Bag SK, Shukla V, Roy S, Tuli R: Oligonucleotide frequencies of barcoding loci can discriminate species across kingdoms. PLOS One 2010, 5:e12330.

79. Botti S, Giuffra E: Oligonucleotide indexing of DNA barcodes: identification of tuna and other scombrid species in food products. BMC Biotechnol 2010, 10:60.

80. Bruni I, De Mattia F, Galimberti A, Galasso G, Banfi E, Casiraghi M, Labra M: Identification of poisonous plants by DNA barcoding approach. Int J Legal Med 2010, 124:595-603.

81. Boehme P, Amendt J, Disney RHL, Zehner R: Molecular identification of carrion-breeding scuttle flies (Diptera: Phoridae) using COI barcodes. Int J Legal Med 2010, 124:577-581.

82. Ferri G, Alù M, Corradini B, Beduschi G: Forensic botany: species identification of botanical trace evidence using a multigene barcoding approach. Int J Legal Med 2009, 123:395-401.

83. Balitzki-Korte B, Anslinger K, Bartsch C, Rolf B: Species identification by means of pyrosequencing the mitochondrial 125 rRNA gene. Int J Legal Med 2005, 119:291-294.

84. Melton T, Holland C: Routine forensic use of the mitochondrial $12 \mathrm{~S}$ ribosomal RNA gene for species identification. J Forensic Sci 2007, 52:1305-1307

85. Kitano T, Umetsu K, Tian W, Osawa M: Two universal primer sets for species identification among vertebrates. Int J Legal Med 2007, 121:423-427.

86. Mitani T, Akane A, Tokiyasu T, Yoshimura S, Okii Y, Yoshida M: Identification of animal species using the partial sequences in the mitochondrial $16 \mathrm{~S}$ rRNA gene. Leg Med (Tokyo) 2009, 11(Suppl 1):S449-S450.

87. Imaizumi K, Akutsu T, Miyasaka S, Yoshino M: Development of species identification tests targeting the $16 \mathrm{~S}$ ribosomal RNA coding region in mitochondrial DNA. Int J Legal Med 2007, 121:184-191.

88. Rastogi G, Dharne MS, Walujkar S, Kumar A, Patole MS, Shouche YS: Species identification and authentication of tissues of animal origin using mitochondrial and nuclear markers. Meat Sci 2007, 76:666-674.

89. Schwenke PL, Rhydderch JG, Ford MJ, Marshall AR, Park LK: Forensic identification of endangered Chinook salmon (Oncorhynchus tshawytscha) using a multilocus SNP assay. Conserv Genet 2006, 7:983-989.

90. Junqueira ACM, Lessinger AC, Torres $\Pi$, da Silva FR, Vettore AL, Arruda P, Azeredo Espin AML: The mitochondrial genome of the blowfly Chrysomya chloropyga (Diptera: Calliphoridae). Gene 2004, 339:7-15.

91. Mayer F, Dietz C, Kiefer A: Molecular species identification boosts bat diversity. Front Zool 2007, 4:4

92. Clifford SL, Anthony NM, Bawe-Johnson M, Abernethy KA, Tutin CEG, White LJT, Bermejo M, Goldsmith ML, McFarland K, Jeffery KJ, Bruford MW, Wickings EJ: Mitochondrial DNA phylogeography of western lowland gorillas (Gorilla gorilla gorilla). Mol Ecol 2004, 13:1551-1565,1567. 
93. Zhang W, Zhang Z, Shen F, Hou R, Lv X, Yue B: Highly conserved D-loop-like nuclear mitochondrial sequences (Numts) in tiger (Panthera tigris). J Genet 2006, 85:107-116

94. Himmelberger AL, Spear TF, Satkoski JA, George DA, Garnica WT, Mallad VS, Smith DG, Webb KM, Allard MW, Kanthaswamy S: Forensic utility of the mitochondrial hypervariable region 1 of domestic dogs, in conjunction with breed and geographic information. J Forensic Sci 2008, 53:81-89.

95. Eichmann C, Parson W: Molecular characterization of the canine mitochondrial DNA control region for forensic applications. Int J Legal Med 2007, 121:411-416.

96. Schneider PM, Seo Y, Rittner C: Forensic mtDNA hair analysis excludes a dog from having caused a traffic accident. Int J Legal Med 1999, 112:315-316.

97. Pun K-M, Albrecht C, Castella V, Fumagalli L: Species identification in mammals from mixed biological samples based on mitochondrial DNA control region length polymorphism. Electrophoresis 2009, 30:1008-1014

98. Nussbaumer C, Korschineck I: Non-human mtDNA helps to exculpate a suspect in a homicide case. Int Congr Ser 2006, 1288:136-138.

99. Fumagalli L, Cabrita CJ, Castella V: Simultaneous identification of multiple mammalian species from mixed forensic samples based on mtDNA control region length polymorphism. Forensic Sci Int Genet Supp/ Ser 2009, 2:302-303.

100. Gilbert MTP, Wilson AS, Bunce M, Hansen AJ, Willerslev E, Shapiro B, Higham TFG, Richards MP, O'Connell TC, Tobin DJ, Janaway RC, Cooper A: Ancient mitochondrial DNA from hair. Curr Biol 2004, 14:R463-R464.

101. Bengtsson CF, Olsen ME, Brandt LØ, Bertelsen MF, Willerslev E, Tobin DJ, Wilson AS, Gilbert MTP: DNA from keratinous tissue: part I: hair and nail. Ann Anat 2012, 194:17-25.

102. Rasmussen M, Li Y, Lindgreen S, Pedersen JS, Albrechtsen A, Moltke I, Metspalu M, Metspalu E, Kivisild T, Gupta R, Bertalan M, Nielsen K, Gilbert MTP, Wang Y, Raghavan M, Campos PF, Kamp HM, Wilson AS, Gledhill A Tridico S, Bunce M, Lorenzen ED, Binladen J, Guo X, Zhao J, Zhang X, Zhang $H$, Li Z, Chen M, Orlando L, et al: Ancient human genome sequence of an extinct Palaeo-Eskimo. Nature 2010, 463:757-762.

103. Melton T, Dimick G, Higgins B, Yon M, Holland C: Mitochondrial DNA analysis of 114 hairs measuring less than $1 \mathrm{~cm}$ from a 19-year-old homicide. Investig Genet 2012, 3:12

104. Gilbert MTP, Janaway RC, Tobin DJ, Cooper A, Wilson AS: Histological correlates of post mortem mitochondrial DNA damage in degraded hair. Forensic Sci Int 2006, 156:201-207.

105. Gilbert MTP, Menez L, Janaway RC, Tobin DJ, Cooper A, Wilson AS: Resistance of degraded hair shafts to contaminant DNA. Forensic Sci Int 2006, 156:208-212

106. Ogle RR, Mitosinka GT: A rapid technique for preparing hair cuticular scale casts. J Forensic Sci 1973, 18:82-83.

107. Cooper A, Poinar HN: Ancient DNA: do it right or not at all. Science 2000, 289:1139.

108. Pääbo S, Poinar H, Serre D, Jaenicke-Despres V, Hebler J, Rohland N, Kuch M, Krause J, Vigilant L, Hofreiter M: Genetic analyses from ancient DNA. Annu Rev Genet 2004, 38:645-679.

109. Willerslev E, Cooper A: Ancient DNA. Proc Biol Sci 2005, 272:3-16.

110. Friedber EC, Walker GC, Siede W, Wood RD, Schulttz RA, Ellenberger T: DNA Repair and Mutagenesis. 2nd edition. Washington DC: ASM Press; 2005.

111. Hansen A, Willerslev E, Wiuf C, Mourier T, Arctander P: Statistical evidence for miscoding lesions in ancient DNA templates. Mol Biol Evol 2001, 18:262-265.

112. Gilbert MTP, Hansen AJ, Willerslev E, Rudbeck L, Barnes I, Lynnerup N, Cooper A: Characterization of genetic miscoding lesions caused by postmortem damage. Am J Hum Genet 2003, 72:48-61.

113. Hofreiter $M$, Jaenicke $V$, Serre $D$, von Haeseler $A$, Pääbo S: DNA sequences from multiple amplifications reveal artifacts induced by cytosine deamination in ancient DNA. Nucleic Acids Res 2001, 29:4793-4799.

114. Bower MA, Spencer M, Matsumura S, Nisbet RER, Howe CJ: How many clones need to be sequenced from a single forensic or ancient DNA sample in order to determine a reliable consensus sequence? Nucleic Acids Res 2005, 33:2549-2556.

115. Timmis JN, Ayliffe MA, Huang CY, Martin W: Endosymbiotic gene transfer: organelle genomes forge eukaryotic chromosomes. Nat Rev Genet 2004 5:123-135.

116. Thalmann O, Hebler J, Poinar HN, Pääbo S, Vigilant L: Unreliable mtDNA data due to nuclear insertions: a cautionary tale from analysis of humans and other great apes. Mol Ecol 2004, 13:321-335.
117. den Tex R-J, Maldonado JE, Thorington R, Leonard JA: Nuclear copies of mitochondrial genes: another problem for ancient DNA. Genetica 2010, 138:979-984.

118. Van der Kuyl AC, Kuiken CL, Dekker JT, Perizonius WR, Goudsmit J: Nuclear counterparts of the cytoplasmic mitochondrial 12S rRNA gene: a problem of ancient DNA and molecular phylogenies. J Mol Evol 1995, 40:652-657.

119. Greenwood AD, Pääbo S: Nuclear insertion sequences of mitochondrial DNA predominate in hair but not in blood of elephants. Mol Ecol 1999. 8:133-137.

120. Greenwood AD, Capelli C, Possnert G, Pääbo S: Nuclear DNA sequences from late Pleistocene megafauna. Mol Biol Evol 1999, 16:1466-1473.

121. Oliveira R, Castro D, Godinho R, Luikart G, Alves PC: Species identification using a small nuclear gene fragment: application to sympatric wild carnivores from South-western Europe. Conserv Genet 2009, 11:1023-1032.

122. Song $H$, Buhay JE, Whiting MF, Crandall KA: Many species in one: DNA barcoding overestimates the number of species when nuclear mitochondrial pseudogenes are coamplified. Proc Natl Acad Sci USA 2008, 105:13486-13491.

123. Barnes I, Matheus P, Shapiro B, Jensen D, Cooper A: Dynamics of Pleistocene population extinctions in Beringian brown bears. Science 2002, 295:2267-2270.

124. Verginelli F, Capelli C, Coia V, Musiani M, Falchetti M, Ottini L, Palmirotta R, Tagliacozzo A, De Grossi Mazzorin I, Mariani-Costantini R: Mitochondrial DNA from prehistoric canids highlights relationships between dogs and south-east European wolves. Mol Biol Evol 2005, 22:2541-2551.

125. Gundry RL, Allard MW, Moretti TR, Honeycutt RL, Wilson MR, Monson KL, Foran DR: Mitochondrial DNA analysis of the domestic dog: control region variation within and among breeds. J Forensic Sci 2007, 52:562-572.

126. Primer3. [http://frodo.wi.mit.edu/primer3/input.htm]

127. Kim KS, Lee SE, Jeong HW, Ha JH: The complete nucleotide sequence of the domestic dog (Canis familiaris) mitochondrial genome. Mol Phylogenet Evol 1998, 10:210-220.

128. Larkin MA, Blackshields G, Brown NP, Chenna R, McGettigan PA, McWilliam H, Valentin F, Wallace IM, Wilm A, Lopez R, Thompson JD, Gibson TJ, Higgins DG Clustal W and Clustal X version 2.0. Bioinformatics 2007, 23:2947-2948.

129. Basic Local Alignment Search Tool. [blast.ncbi.nlm.nih.gov]

130. Coghlan ML, White NE, Murray DC, Houston J, Rutherford W, Bellgard MI, Haile J, Bunce M: Metabarcoding avian diets at airports: implications for birdstrike hazard management planning. Investig Genet 2013, 4:27.

131. Tamura K, Stecher G, Peterson D, Filipski A, Kumar S: MEGA6: molecular evolutionary genetics analysis version 6.0. Mol Biol Evol 2013, 30:2725-2729.

132. Edgar RC: MUSCLE: multiple sequence alignment with high accuracy and high throughput. Nucleic Acids Res 2004, 32:1792-1797.

133. Saitou N, Nei M: The neighbor-joining method: a new method for reconstructing phylogenetic trees. Mol Biol Evol 1987, 4:406-425.

134. Wheeler B, Wilson LJ: Animal hair examinations. In Practical Forensic Microscopy: A Laboratory Manual. Chichester: Wiley; 2008:160-169.

135. Deedrick DW, Koch SL: Microscopy of hair Part II: a practical guide and manual for animal hairs. Forensic Sci Commun 2004, 6: [http://www.fbi.gov/ about-us/lab/forensic-science-communications/fsc/july2004/research/ 200403 research02.htm]

136. Arbidar Fiber and Hair Collections. [http://www.microtracellc.com/service/ arbidar-reference-collections]

137. Lindahl T: Instability and decay of the primary structure of DNA. Nature 1993, 362:709-715.

138. Pääbo S: Ancient DNA: extraction, characterization, molecular cloning, and enzymatic amplification. Proc Natl Acad Sci U S A 1989, 86:1939-1943.

139. Höss M, Jaruga P, Zastawny TH, Dizdaroglu M, Pääbo S: DNA damage and DNA sequence retrieval from ancient tissues. Nucleic Acids Res 1996, 24:1304-1307.

140. Mitchell D, Willerslev E, Hansen A: Damage and repair of ancient DNA. Mutat Res 2005, 571:265-276

141. Chen L, Zhang HH: Nyctereutes procyonoides Mitochondrion, Complete Genome. GenBank: GU256221.1. [http://www.ncbi.nlm.nih.gov/nuccore/ GU256221.1]

142. Bär W, Kratzer A, Mächler M, Schmid W: Postmortem stability of DNA Forensic Sci Int 1988, 39:59-70.

143. Lindahl T, Nyberg B: Rate of depurination of native deoxyribonucleic acid. Biochemistry 1972, 11:3610-3618.

144. Kimura M: A simple method for estimating evolutionary rates of base substitutions through comparative studies of nucleotide sequences. J Mol Evol 1980, 16:111-120. 
145. Tamura K: Estimation of the number of nucleotide substitutions when there are strong transition-transversion and $\mathrm{G}+\mathrm{C}$-content biases. Mol Biol Evol 1992, 9:678-687.

146. Vilà C, Savolainen P, Maldonado JE, Amorim IR, Rice JE, Honeycutt RL, Crandall KA, Lundeberg J, Wayne RK: Multiple and ancient origins of the domestic dog. Science 1997, 276:1687-1689.

147. Webb KM, Allard MW: Identification of forensically informative SNPs in the domestic dog mitochondrial control region. J Forensic Sci 2009, 54:289-304.

148. Angleby $H$, Savolainen P: Forensic informativity of domestic dog mtDNA control region sequences. Forensic Sci Int 2005, 154:99-110.

149. Shahid SA, Xiao Y, Khan S, Feng D, Johnson GS, Ha J: Canis lupus familiaris Isolate 1 Breed Welsh Springer Spaniel Mitochondrion, Complete Genome. GenBank: AY656747.1. [http://www.ncbi.n/m.nih.gov/nuccore/AY656747]

150. Pang J-F, Kluetsch C, Zou X-J, Zhang A, Luo L-Y, Angleby H, Ardalan A, Ekström C, Sköllermo A, Lundeberg J, Matsumura S, Leitner T, Zhang Y-P, Savolainen P: mtDNA data indicate a single origin for dogs south of Yangtze River, less than 16,300 years ago, from numerous wolves. Mol Biol Evol 2009, 26:2849-2864.

151. Savolainen P, Zhang Y, Luo J, Lundeberg J, Leitner T: Genetic evidence for an East Asian origin of domestic dogs. Science 2002, 298:1610-1613.

152. Imes DL, Wictum EJ, Allard MW, Sacks BN: Identification of single nucleotide polymorphisms within the mtDNA genome of the domestic dog to discriminate individuals with common HVI haplotypes. Forensic Sci Int Genet 2012, 6:630-639.

153. Kim K, Jeong H, Sohn $\mathrm{H}, \mathrm{Ha}$ J: Canis familiaris Breed Jindo Mitochondrial D-Loop, Partial Sequence. Genbank: AF064569.1. [http://www.ncbi.nlm. nih.gov/nuccore/AF064569]

154. Kasuga M, Sugiyama S, Tsuchida S, Omi T: Canis lupus familiaris DNA, Hypervariable Region 1 (Control Region), Partial Sequence, Haplotype: NVLU057 Genbank: AB700664.1. [http://www.ncbi.n/m.nih.gov/nuccore/ AB700664]

155. Zhang J, Zhao C, Liu GS, Chen L, Zhang HH: Canis lupus laniger Mitochondrion, Complete Genome. Genbank: KF573616.1. [http://www. ncbi.nlm.nih.gov/nuccore/KF573616]

156. Meng C, Zhang H, Meng Q: Canis lupus laniger Mitochondrion, Complete Genome. GenBank: FJ032363.2. [http://www.ncbi.nlm.nih.gov/nuccore/ FJ032363]

157. Tsuda K, Kikkawa Y, Yonekawa H, Tanabe Y: Extensive interbreeding occurred among multiple matriarchal ancestors during the domestication of dogs: evidence from inter- and intraspecies polymorphisms in the D-loop region of mitochondrial DNA between dogs and wolves. Genes Genet Syst 1997, 72:229-238.

158. Ishiguro N, Inoshima Y, Shigehara N: Mitochondrial DNA analysis of the Japanese wolf (Canis lupus hodophilax Temminck, 1839) and comparison with representative wolf and domestic dog haplotypes. Zoolog Sci 2009, 26:765-770

159. Sharma DK, Maldonado JE, Jhala YV, Fleischer RC: Ancient wolf lineages in India. Proc Biol Sci 2004, 271(Suppl 3):S1-S4

160. Meng C, Zhang H: Canis lupus chanco Mitochondrion, Complete Genome. GenBank: EU442884.2. [http://www.ncbi.nlm.nih.gov/nuccore/EU442884]

161. Dou H: Canis lupus chanco Haplotype 1 D-Loop, Partial Sequence; Mitochondrial. GenBank: JX415343.1. [http://www.ncbi.nlm.nih.gov/ nuccore/JX415343]

162. Nonaka N, Sano T, Inoue T, Fukui D, Katakura K, Oku Y: Nyctereutes procyonoides Mitochondrial DNA, D-Loop Region, Partial Sequence, isolate:R1. GenBank: AB292740.1. [http://www.ncbi.nlm.nih.gov/nuccore/ AB292740]

163. Okumura N, Ishiguro N, Nakano M, Matsui A, Sahara M: Intra- and interbreed genetic variations of mitochondrial DNA major non-coding regions in Japanese native dog breeds (Canis familiaris). Anim Genet 1996, 27:397-405.

164. Park SK, Lee M-Y, Min MS, Lee H: Nyctereutes procyonoides Haplotype L_179 D-Loop, Partial Sequence; Mitochondrial. GenBank: EU642411.1. [http://www.ncbi.n/m.nih.gov/nuccore/EU642411]

165. Pitra C, Schwarz S, Fickel J: Going west - invasion genetics of the alien raccoon dog Nyctereutes procynoides in Europe. Eur J Wildl Res 2009, 56:117-129.

166. Korablev NP, Korablev MP, Rozhnov W, Korablev PN: Polymorphism of the mitochondrial DNA control region in the population of raccoon dog (Nyctereutes procyonoides Gray, 1834) introduced into the Upper Volga basin. Russ J Genet 2011, 47:1227-1233.
167. Paulauskas A, Griciuviene L, Radzijevskaja J, Gedminas V: Nyctereutes procyonoides Isolate LV1 D-Loop, Partial Sequence; Mitochondrial. GenBank: KC509604.1. [http://www.ncbi.nlm.nih.gov/nuccore/KC509604]

168. Chen L, Zhang HH: Nyctereutes procyonoides Mitochondrion, Complete Genome. NCBI Reference Sequence: NC_013700.1. [http://www.ncbi.nlm nih.gov/nuccore/NC 013700]

169. Wodecka B, Rymaszewska A, Skotarczak B: Host and pathogen DNA identification in blood meals of nymphal Ixodes ricinus ticks from forest parks and rural forests of Poland. Exp Appl Acarol 2014, 62:543-555.

170. Driscoll CA, Macdonald DW, O'Brien SJ: From wild animals to domestic pets, an evolutionary view of domestication. Proc Natl Acad Sci U S A 2009, 106(Suppl 1):9971-9978.

171. Driscoll CA, Menotti-Raymond M, Roca AL, Hupe K, Johnson WE, Geffen E, Harley EH, Delibes M, Pontier D, Kitchener AC, Yamaguchi N, O'Brien SJ, Macdonald DW: The Near Eastern origin of cat domestication. Science 2007, 317:519-523

doi:10.1186/2041-2223-5-7

Cite this article as: Pilli et al:: Pet fur or fake fur? A forensic approach. Investigative Genetics 2014 5:7.

\section{Submit your next manuscript to BioMed Central and take full advantage of:}

- Convenient online submission

- Thorough peer review

- No space constraints or color figure charges

- Immediate publication on acceptance

- Inclusion in PubMed, CAS, Scopus and Google Scholar

- Research which is freely available for redistribution 